Article

\title{
Antimicrobial Activity and DFT Studies of a Novel Set of Spiropyrrolidines Tethered with Thiochroman-4-one/Chroman-4-one Scaffolds
}

\author{
Nourhène Chouchène ${ }^{1}$, Amani Toumi ${ }^{1}$, Sarra Boudriga ${ }^{1, *(D)}$, Hayet Edziri ${ }^{2}$, Mansour Sobeh ${ }^{3}(\mathbb{D}$, \\ Mohamed A. O. Abdelfattah ${ }^{4}$, Moheddine Askri ${ }^{1}$, Michael Knorr ${ }^{5, * \mathbb{D}}$, Carsten Strohmann ${ }^{6}$, \\ Lukas Brieger ${ }^{6}$ and Armand Soldera ${ }^{7, *}$
}

1 Laboratory of Heterocyclic Chemistry Natural Product and Reactivity (LR11ES39), Department of Chemistry, Faculty of Science of Monastir, University of Monastir, Monastir 5019, Tunisia; nourhene.chouchene23@gmail.com (N.C.); amanitoumi45@gmail.com (A.T.); moheddine.askri@fsm.rnu.tn (M.A.)

2 Laboratoire des Maladies Transmissibles et des Substances Biologiquement Actives, Faculté de Pharmacie, Monastir 5000, Tunisia; jaziri_hayet@yahoo.fr

3 AgroBioSciences Research, Mohammed VI Polytechnic University, Lot 660-Hay MoulayRachid, Ben Guerir 43150, Morocco; mansour.sobeh@um6p.ma

4 College of Engineering and Technology, American University of the Middle East, Kuwait; Mohamed.AbdelMoety@aum.edu.kw

check for updates

Citation: Chouchène, N.; Toumi, A.; Boudriga, S.; Edziri, H.; Sobeh, M.; Abdelfattah, M.A.O.; Askri, M.; Knorr, M.; Strohmann, C.; Brieger, L.; et al. Antimicrobial Activity and DFT Studies of a Novel Set of

Spiropyrrolidines Tethered with Thiochroman-4-one/Chroman-4-one Scaffolds. Molecules 2022, 27, 582. https://doi.org/10.3390/ molecules27030582

Academic Editors: Jean-Marc Sabatier, Soumaya Kouidhi and Athina Geronikaki

Received: 29 October 2021 Accepted: 20 December 2021 Published: 18 January 2022

Publisher's Note: MDPI stays neutral with regard to jurisdictional claims in published maps and institutional affiliations.

Copyright: (C) 2022 by the authors. Licensee MDPI, Basel, Switzerland. This article is an open access article distributed under the terms and conditions of the Creative Commons Attribution (CC BY) license (https:// creativecommons.org/licenses/by/ $4.0 /)$.
5 Institut UTINAM-UMR CNRS 6213, Université Bourgogne Franche-Comté, 16 Route de Gray, 25030 Besançon, France

6 Faculty of Chemistry, Inorganic Chemistry, Technical University Dortmund, Otto-Hahn-Strasse 6 , 44227 Dortmund, Germany; carsten.strohmann@tu-dortmund.de (C.S.); lukas.brieger@tu-dortmund.de (L.B.)

7 Laboratory of Physical Chemistry of Matter, Department of Chemistry, Université de Sherbrooke, Sherbrooke, QC J1K 2R1, Canada

* Correspondence: sarra.boudriga@fsm.rnu.tn (S.B.); michael.knorr@univ-fcomte.fr (M.K.); armand.soldera@usherbrooke.ca (A.S.)

\begin{abstract}
A novel series of 14 spiropyrrolidines bearing thiochroman-4-one/chroman-4-one, and oxindole/acenaphthylene-1,2-dione moieties were synthesized and characterized by spectroscopic techniques, as well as by three X-ray diffraction studies, corroborating the stereochemistry. Quantum chemical calculations studies, using the DFT approach, were performed to rationalize the stereochemical outcome. These $\mathrm{N}$-heterocycles were evaluated for their antibacterial and antifungal activities against some pathogenic organisms. Several compounds displayed moderate to excellent activity towards the screened microbe strains in the study compared to Amoxicillin (AMX), Ampicillin (AMP), and Amphotericin B. Furthermore, a structural activity relationship (SAR) was established considering the synthesized compounds. Pharmacokinetic studies reveal that these derivatives exhibit an acceptable predictive ADMET profile (Absorption, Distribution, Metabolism, Excretion and Toxicity) and good drug-likeness.
\end{abstract}

Keywords: [3+2] cycloaddition; thiochroman-4-one; chroman-4-one; spiropyrrolidine; crystal structure; DFT

\section{Introduction}

The emergence of drug-resistant pathogens has threatened human ability to treat common infections, and, thus, antimicrobial resistance (AMR) became a health threat all over the globe. The rapid spread of Staphylococcus aureus, for instance, is especially alarming, since it is considered to be among the most common causes of infections in healthcare facilities [1,2]. Furthermore, patients suffering with infections caused by methicillinresistant Staphylococcus aureus (MRSA) are more likely to die, compared to others infected with drug-sensitive infections, by about 64\% [3,4]. Consequently, antimicrobial medications including antibiotics are getting more and more ineffective and, thus, infections become 
difficult or nearly impossible to treat. This lowered efficacy urgently increases the demand for new therapeutic agents.

In recent years, spiropyrrolidine scaffolds, especially those fused to oxindole or acenaphthylene-1(2H)-one moieties, and occurring in a huge number of pharmacological entities and natural compounds with significant bioactive properties, have attracted the attention of synthetic chemists [5-13] (Figure 1).
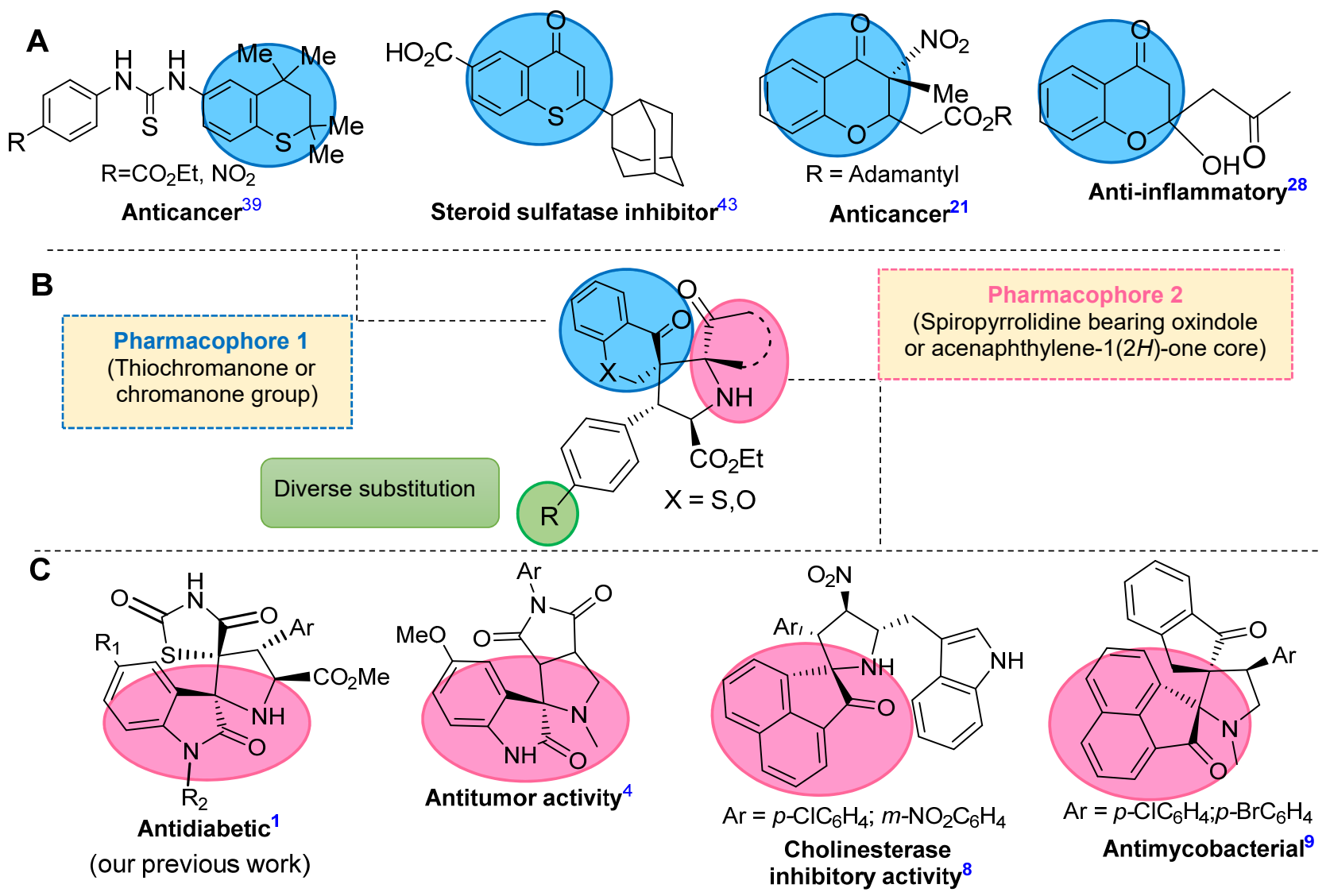

Figure 1. (A) Biologically relevant thiochroman, thiochromanone, and chromanone derivatives, (C) Biologically relevant spiropyrrolidines bearing oxindole or acenaphthylene-1(2H)-one moieties, and (B) Our target compounds.

On the other hand, 4-chromanone derivatives represent privileged scaffolds in heterocyclic chemistry and for drug discovery. They are used as versatile intermediates for the synthesis of many natural products [14-19] and constitute interesting building blocks in drug design and organic synthesis [20-23]. They also exhibit significant biological activities allowing their use as anticancer [24-27], antifungal and antibacterial [28-31], anti-inflammatory [32,33], antidiabetic [34,35], anti-leishmanial (caused by protozoan parasites) [36,37], and insecticidal agents [38] (Figure 1).

Thiochromanones, the thio-analogs of chromanones, feature interesting scaffolds, which have been reported to exert a plethora of pronounced biological and pharmacological properties including antimicrobial [39-42], anticancer [43-46], human steroid sulfatase inhibition [47,48], $\alpha$-adrenergic antagonist [49], antiviral [50], and insecticidal activities [51] (Figure 1).

In light of the significance of spiropyrrolidine and thiochromanone/chromanone heterocycles in medicinal chemistry, we felt a great potential to combine these two moieties into one single scaffold to design a novel class of hybrid spiroheterocycles, which may exhibit interesting biological profiles. The latter were obtained via multicomponent reactions (MCRs) of arylidene thiochroman-4-ones/chroman-4-ones, glycine ethyl ester, and cyclic 
1,2-diketones (isatin derivatives or acenaphthenequinone) (Scheme 1). We are aware that related spiropyrrolidine(s) fused with thiochroman-4-one/chroman-4-one moieties have been prepared by Subramaniyan [52] and Rani [53], however their pharmacological profile has, up to now, never been explored.

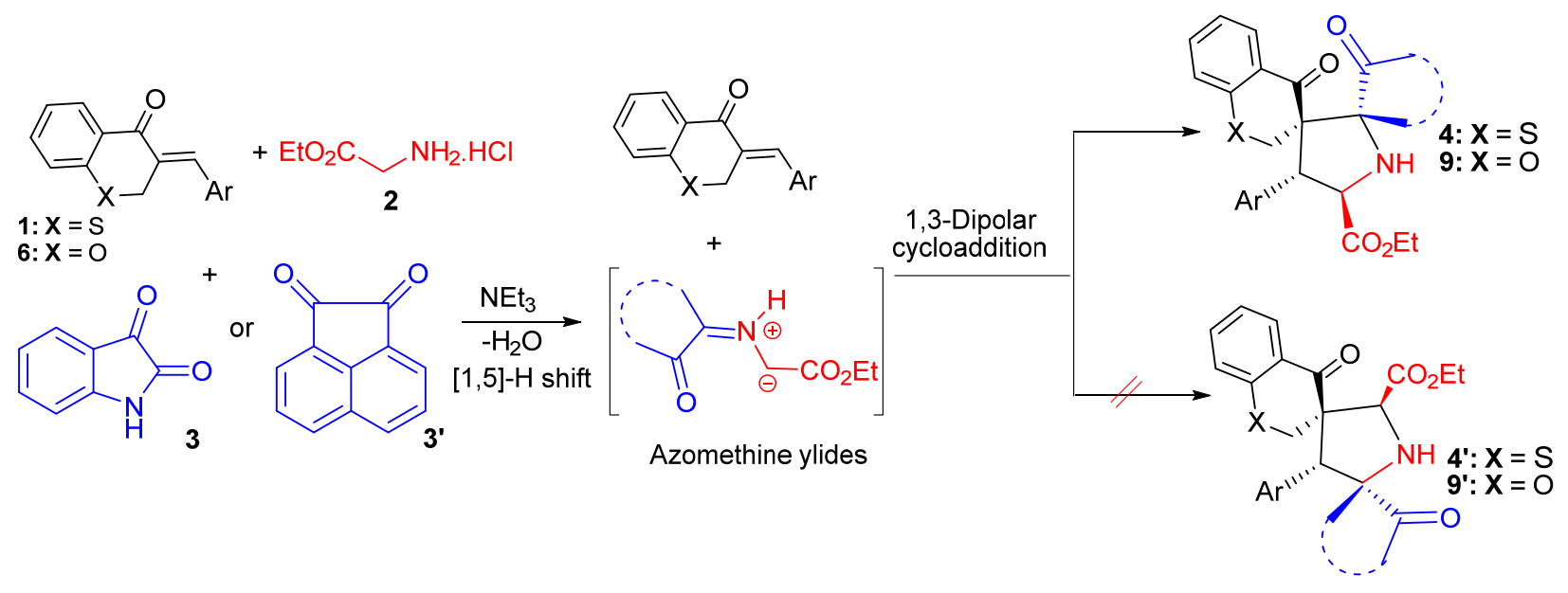

Scheme 1. Synthesis scheme for the target compounds 4 and 9.

In continuation of our research interests in the synthesis of novel bioactive $N$-spirohete -rocycles [5,54-57], we herein report the synthesis of diverse thiochromanone/chromanone substituted spiropyrrolidines (Figure 1). The latter were obtained via multicomponent reactions (MCRs) of arylidene thiochroman-4-ones/chroman-4-ones, glycine ethyl ester, and cyclic 1,2-diketones (isatin derivatives or acenaphthenequinone) (Scheme 1). These new scaffolds were tested in vitro for their antimicrobial potential. DFT calculations were carried out to obtain the optimized molecular structures of the resulting spiranic thiochromanone/chromanone-linked spiropyrrolidines. Furthermore, frontiers molecular orbitals (FMO) and molecular electrostatic potential (MEP) calculations were performed for the structural exploration of these compounds. A drug-likeness analysis was also performed.

\section{Results and Discussion}

\subsection{Synthetic Chemistry}

The synthetic strategy for our target compounds 4 and 9 is shown in Scheme 1 . It is based on a multicomponent process involving the 1,3-dipolar cycloaddition reaction between exocyclic arylated alkenes derived from thiochromanone $\mathbf{1}$ or chromanone $\mathbf{6}$ and azomethine ylides. The latter were generated in situ from condensation of glycine ethyl ester 2 and a 1,2-diketone, namely isatin 3 or acenaphthenequinone $\mathbf{3}^{\prime}$ (Scheme 1).

At the onset of our investigation, we attempted to access the hybrid thiochromanonegrafted spiropyrrolidines according to our recently established reaction conditions for MCR of arylidene rhodanines, glycine ethyl ester, and cyclic 1,2-diketones [5]. For that purpose, an equivalent amount of 3-benzylidenethiochroman-4-one 1a, glycine ethyl ester $\mathbf{2}$, and isatin 3 was refluxed in acetonitrile in the presence of triethylamine for $2 \mathrm{~h}$. The reaction smoothly afforded the desired spiroheterocycle $\mathbf{4 a}$ in $80 \%$ yield (Table 1). Subsequently, a variety of dipolarophiles 1 were subjected to these reaction conditions. As shown in Table 1, this process is applicable to a wider series of arylidene thiochromanones 1 bearing electronically different substituents, or groups, on the phenyl ring, affording in good yields the targeted spiropyrrolidine products $4 \mathbf{b}-\mathbf{d}$ in a high regio- and diastereoselective manner as racemic mixtures. To expand the scope of this protocol, we further examined the multicomponent reaction with acenaphthenequinone $\mathbf{3}^{\prime}$ as an alternative 1,2-diketone, instead of isatin 3 (Table 1), to synthetize an original spiropyrrolidines scaffold bearing an acenaphthylen-1 $(2 H)$-one core. The azomethine ylide derived from acenaph- 
thenequinone seemed to be well appropriate for this process, affording the corresponding exo-spirropyrrolidine-chromanones $\mathbf{4 e}$ and $\mathbf{4} \mathbf{f}$ with good yields. Since this straightforward multicomponent [3+2] cycloaddition worked efficiently, we then studied the scope of the reaction using an oxygen surrogate, namely 5 -arylidene chroman-4-ones 6 , under the same reaction conditions (Table 2).

Table 1. Synthesis of spiropyrrolidine-thiochroman-4-ones hybrids 4 .

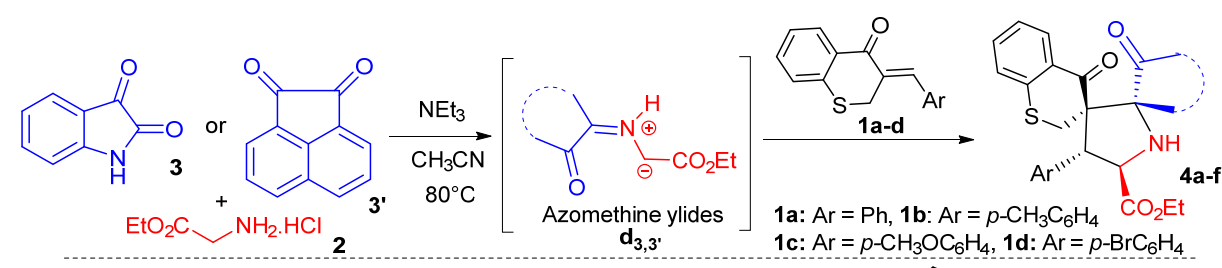

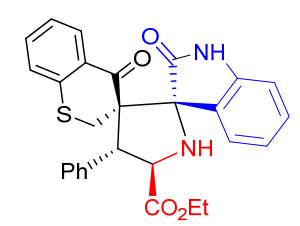

4a, $80 \%$

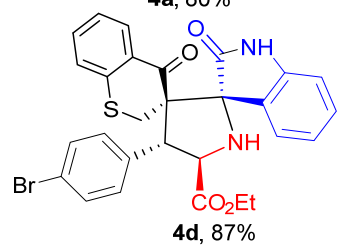

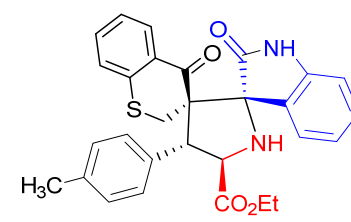

4b, $85 \%$

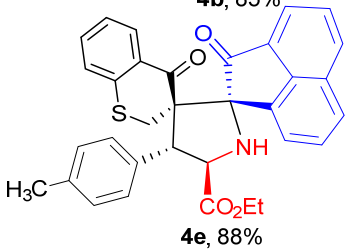

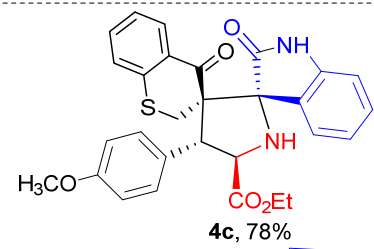

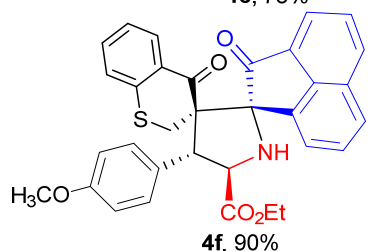

All reactions were carried out using 1 (1 mmol), 2 (1 mmol), 3, or $\mathbf{3}^{\prime}(1 \mathrm{mmol}), \mathrm{NEt}_{3}(1 \mathrm{mmol})$ in $\mathrm{CH}{ }_{3} \mathrm{CN}(5.0 \mathrm{~mL})$ at reflux for $2 \mathrm{~h}$. Yields of the isolated cycloadducts are given.

Table 2. Synthesis of acenaphthylen-1(2H)-one-spiropyrrolidine-chromanone hybrids 9.

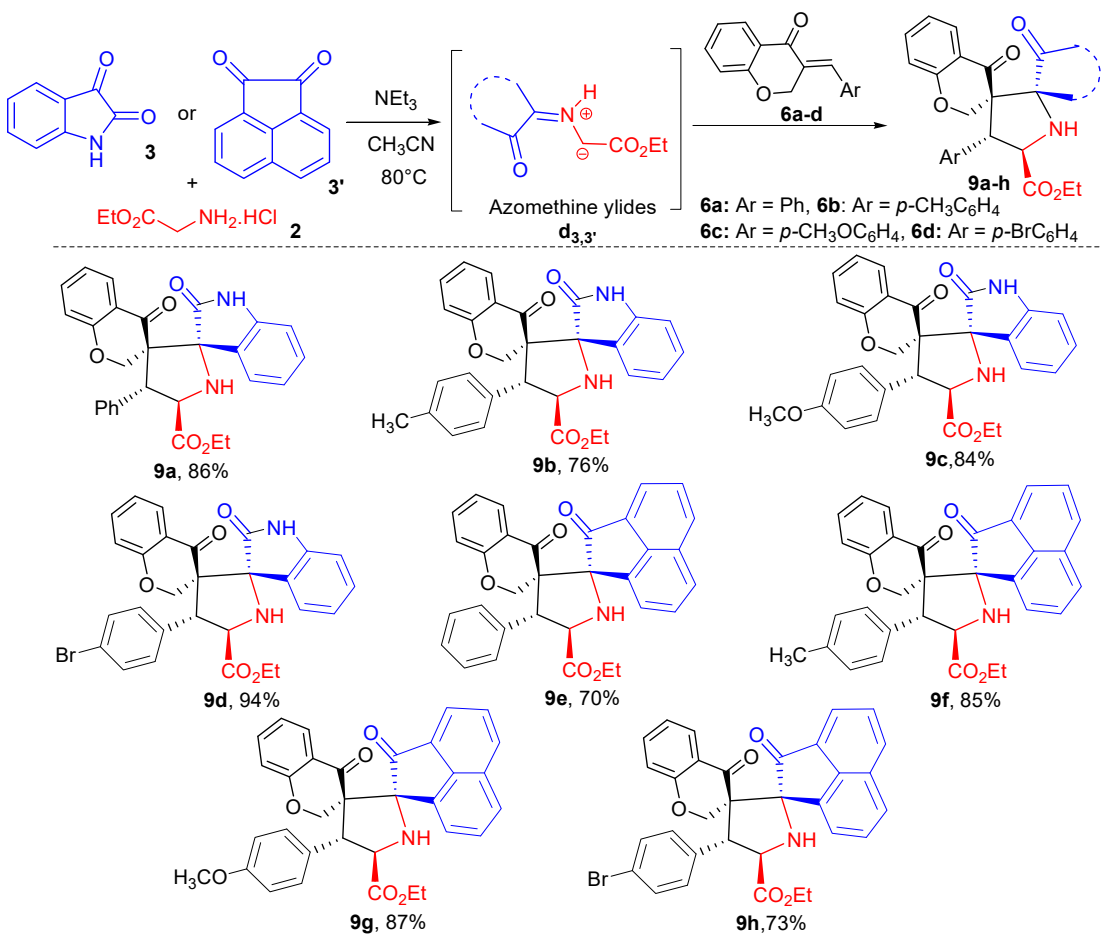

All reactions were carried out using $6(1 \mathrm{mmol}), 2(1 \mathrm{mmol}), 3$, or $3^{\prime}(1 \mathrm{mmol}), \mathrm{NEt}_{3}(1 \mathrm{mmol})$ in $\mathrm{CH}_{3} \mathrm{CN}(5.0 \mathrm{~mL})$ at reflux for $2 \mathrm{~h}$. Yields of the isolated cycloadducts are given. 
The MCR proceeded readily providing the spiropyrrolidines exo-9a-h as the only detectable diastereoisomers (TLC monitoring) with good to excellent yield (70-94\%), regardless of the electronic nature of the $p$-substituent at the aryl group $\left(\mathrm{H}, \mathrm{OCH}_{3}, \mathrm{CH}_{3}\right.$, and $\left.\mathrm{Cl}\right)$ of the dipolarophile 6 . On the other hand, the steric property of the acenaphthenequinone $3^{\prime}$ had almost a negligible effect on the efficiency of the 1,3-dipolar cycloaddition reaction, which proceeded smoothly producing the acenaphthylen-1(2H)-one spiropyrrolidinechromanones $\mathbf{9 e}-\mathbf{h}$ in excellent yields. All compounds are stable and were obtained as colorless or yellow solids.

\subsubsection{Spectroscopic and Crystallographic Characterization of Cycloadducts 4 and 9}

The composition and stereochemistry of the chromanone/thiochromanone-grafted spiropyrrolidines was unambiguously elucidated by their spectroscopic data and elemental analyses. The assignments of the chemical shifts from the ${ }^{1} \mathrm{H}$ and ${ }^{13} \mathrm{C}$ NMR spectra of the studied compounds were done based on the literature data $[5,53,55]$ and calculations at the B3LYP/6-311++G(2d,p) level of compounds 4a and 9c (Supplementary Materials; Table S1). As representative examples, relevant ${ }^{1} \mathrm{H}$ and ${ }^{13} \mathrm{C}$ chemical shifts of spiro-compounds $4 \mathbf{a}$ and $9 \mathrm{c}$ are illustrated in Figures 2 and 3, respectively.

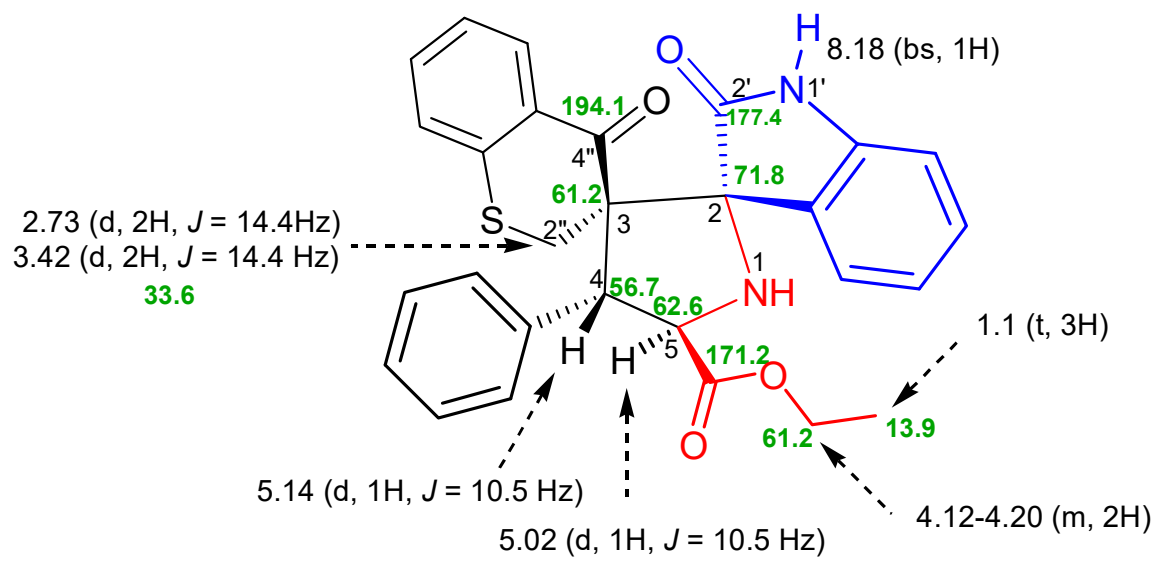

$4 a$

Figure 2. ${ }^{1} \mathrm{H}$ (black) and ${ }^{13} \mathrm{C}\left\{{ }^{1} \mathrm{H}\right\} \mathrm{NMR}$ (green) chemical shifts (ppm) of the selected compound 4a (see also Figure S3 in the Supporting Material).

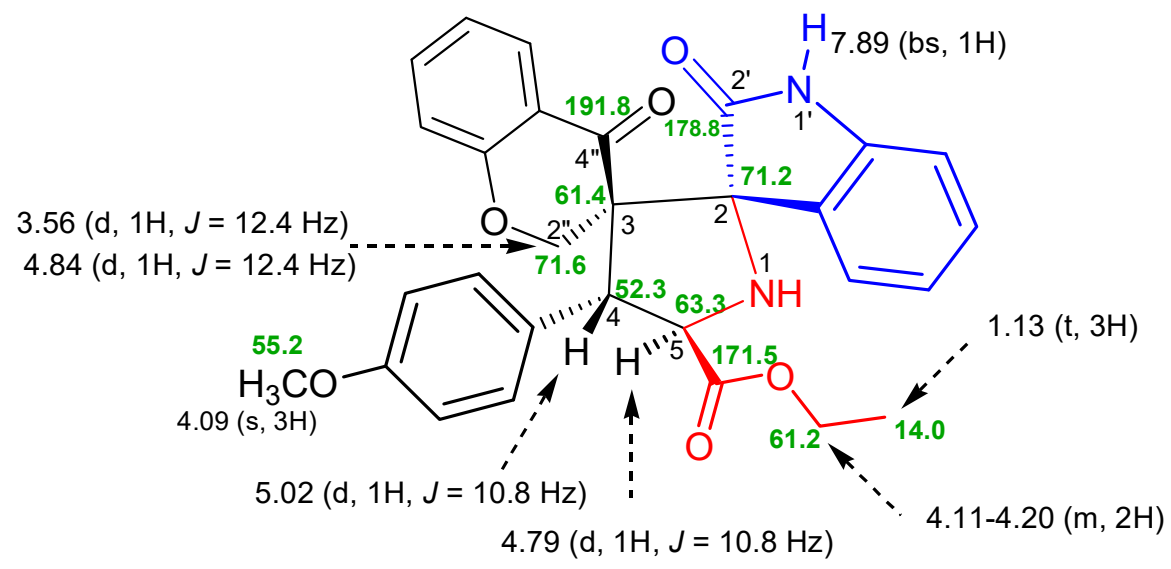

9c

Figure 3. ${ }^{1} \mathrm{H}$ (black) and ${ }^{13} \mathrm{C}\left\{{ }^{1} \mathrm{H}\right\}$ NMR (green) chemical shifts (ppm) of the selected compound 9c (see also Figure S20 in the Supporting Material). 
In the ${ }^{1} \mathrm{H}$ NMR spectra of $\mathbf{4 a}$ and $\mathbf{9 c}$, the pyrrolidinyl protons $\mathrm{H}-4$ and $\mathrm{H}-5$ appear as two mutually coupled doublets at $\delta 5.14$ and $5.02 \mathrm{ppm}$, and $\delta 5.02$ and $4.79 \mathrm{ppm}$, respectively. This multiplicity unambiguously confirms the regiochemistry proposed in Figures 2 and 3. If the hypothetical alternative regioisomers $4^{\prime}, \mathbf{9}^{\prime}$ (Scheme 1) would have been formed, the pyrrolidinyl protons should give rise to two singlets in the ${ }^{1} \mathrm{H}$ NMR spectrum. Furthermore, the value of the ${ }^{3} J$ coupling constants of 10.5 and $10.8 \mathrm{~Hz}$ indicate that $\mathrm{H}-4$ and $\mathrm{H}-5$ protons are in trans relationship, in accordance with our earlier reports on related compounds [5,55]. A broadened singlet at $\delta 8.18$ and $7.89 \mathrm{ppm}$ can be assigned to the oxindole $\mathrm{N}-\mathrm{H}$ proton of $4 \mathbf{a}$ and $\mathbf{9 c}$, and a multiplet in the region between $6.59-8.17 \mathrm{ppm}$ and 6.06-7.94 ppm indicates the presence of aromatic protons. Additionally, the ${ }^{1} \mathrm{H}$ NMR spectra show two mutually coupled doublets at $\delta 2.73$ and $3.42 \mathrm{ppm}$ for $4 \mathrm{a}$, and 3.56 and $4.84 \mathrm{ppm}$ for $9 \mathrm{c}$, corresponding to the diastereotopic $2^{\prime}-\mathrm{CH}_{2}$ group. The ${ }^{3} J$ values of $12.3 \mathrm{~Hz}$ for $4 \mathbf{a}$ and $14.1 \mathrm{~Hz}$ for $9 \mathrm{c}$ are in the same range with those previously reported values of similar spiropyrrolidine(s) fused with thiochroman-4-one/chroman-4-one moieties [52,53].

The proton decoupled ${ }^{13} \mathrm{C}$ NMR spectrum of $9 \mathrm{c}$ reveals the presence of two signals at $\delta 191.8$ and $\delta 178.8 \mathrm{ppm}$, attributed to the carbonyl groups of chromanone and oxindole moieties, respectively. The resonances corresponding to the two spirocarbons C-2 and C-3 are observed at $\delta 71.2$ and $\delta 61.4 \mathrm{ppm}$, respectively. For the assignment of the methoxy, methylene, methine, spiro, and quaternatry carbons, the DEPT- 135 spectra shown in Figures S3 and S20 were recorded.

The relative configuration of the stereogenic carbons in spiropyrrolidines 4 and 9 was corroborated after determination of the single-crystal X-ray structures of cycloadducts $4 \mathbf{a}, 4 \mathbf{e}$, and $9 \mathbf{c}$, whose molecular structures are shown in Figures 4-6, respectively. The structural analysis reveals that the carbonyl carbon of acenaphthenequinone moiety and (i) the carbonyl carbon group of thiochromanone/chromanone part are in trans-relationship, (ii) the pyrrolidinyl proton attached at C-5 (C-11, C-4, and C-18 in the crystal structures of $4 \mathbf{a}, 4 \mathbf{e}$, and $9 \mathbf{c}$, respectively) are in cis-relationship (note that the crystallographic atom numbering scheme differs from that used in Figures 2 and 3).

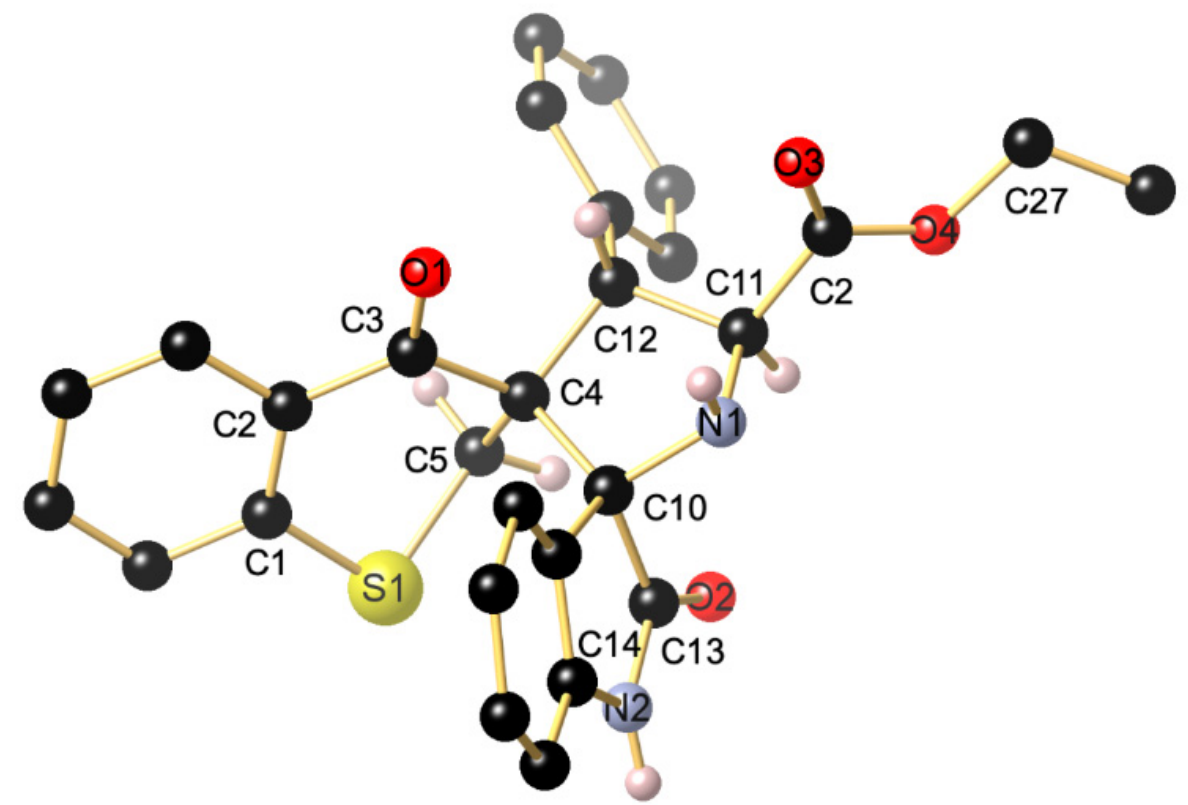

Figure 4. Ball and sticks presentation of the molecular structure of 4 a recorded at $100 \mathrm{~K}$. Only one of the two independent molecules is shown. Apart from stereochemically relevant $\mathrm{H}$ atoms, all other hydrogen atoms are omitted for clarity. Furthermore, an EtOH molecule of crystallization, present in the asymmetric unit, is not depicted. 


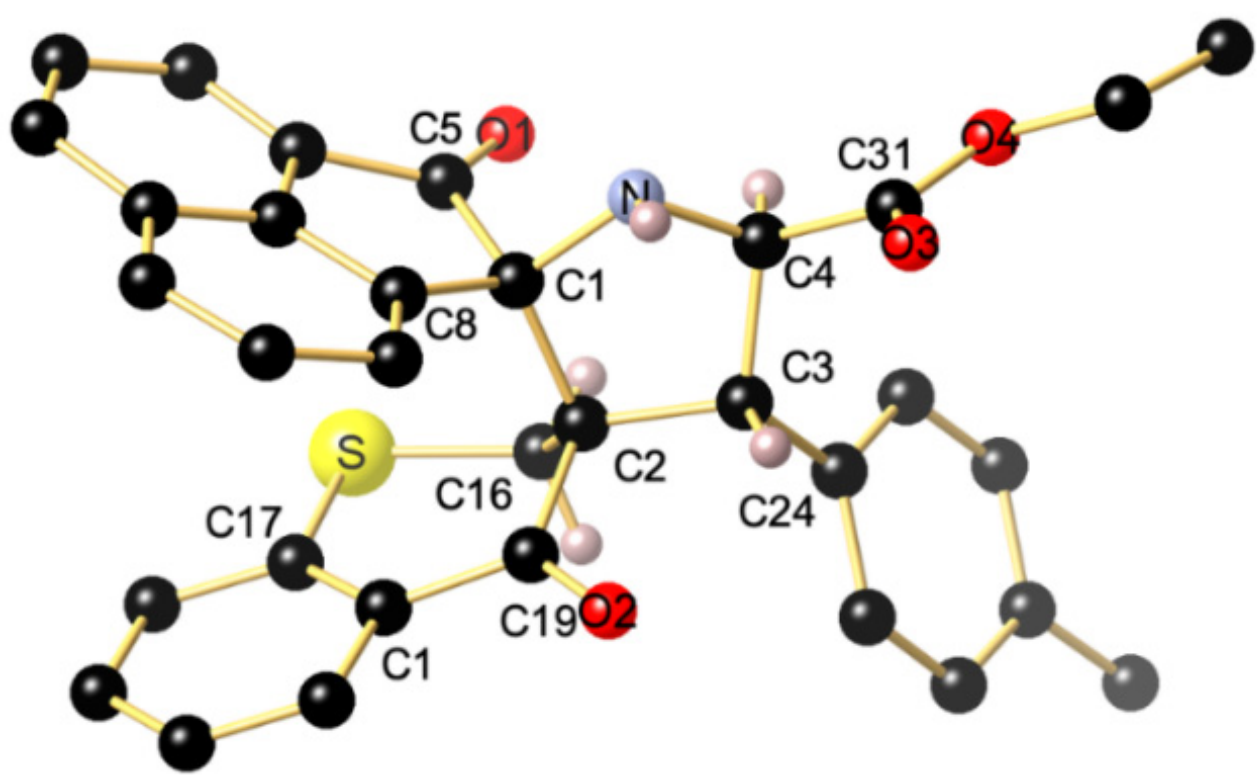

Figure 5. Ball and sticks presentation of the molecular structure of 4 e recorded at $100 \mathrm{~K}$. Only stereochemically relevant $\mathrm{H}$ atoms are shown.

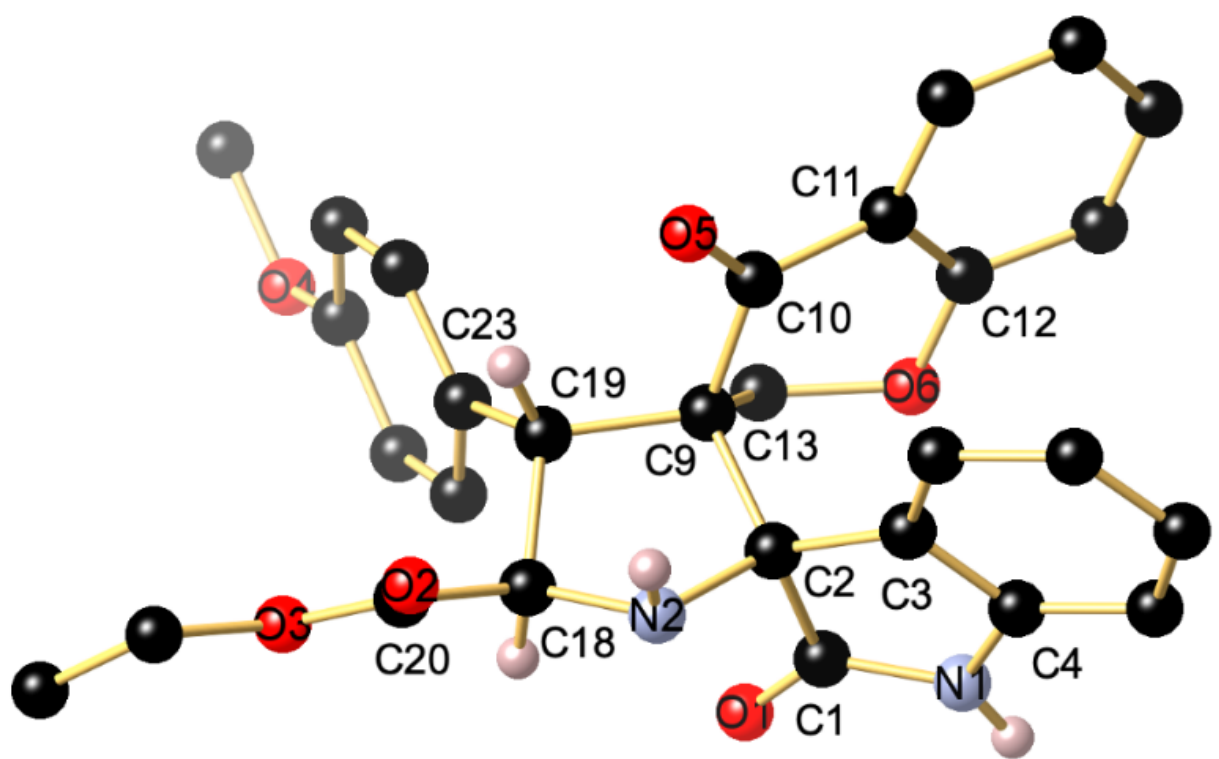

Figure 6. Ball and sticks presentation of the molecular structure of 9c recorded at $100 \mathrm{~K}$. Only one of the two independent molecules is shown. Apart from stereochemically relevant $\mathrm{H}$ atoms, all other hydrogen atoms are omitted for clarity.

It is noteworthy that the packing of 4 a contains two independent molecules with slightly different metric parameters, and the individual molecules are associated through intermolecular $\mathrm{N}_{2}-\mathrm{H}_{2} \cdots \mathrm{O}_{6}$ and $\mathrm{N}_{4}-\mathrm{H}_{4} \ldots \mathrm{O}_{2}$ hydrogen bonding with $\mathrm{H} \cdots \mathrm{O}$ bond lengths of 1.94 and $2.00 \AA$, respectively (see Figure S31). A similar supramolecular pairwise N$\mathrm{H}$... O association occurs also in the crystal structure of 9c (see Figure S32).

Accordingly, we propose that the cycloadducts 4 and 9 are formed through an exoapproach between the arylidene thiochromanone/chromanone and the Z,E-dipole, as outlined above in Tables 1 and 2. 


\subsubsection{DFT Mechanistic Studies}

To better grasp the experimentally observed high regio- and diastereoselectivity in the MCR, DFT calculations were performed using the 6-31G $(\mathrm{d}, \mathrm{p})$ basis set and the $\omega \mathrm{B} 97 \mathrm{xd}$ functional [58]. The effect of solvent (acetonitrile) was taken into consideration using the polarizable continuum model (PCM) approach $[59,60]$. We have chosen the reaction of dipolarophile 1a, glycine ethyl ester 2, and isatin 3 as model case study, as illustrated in Scheme 2.

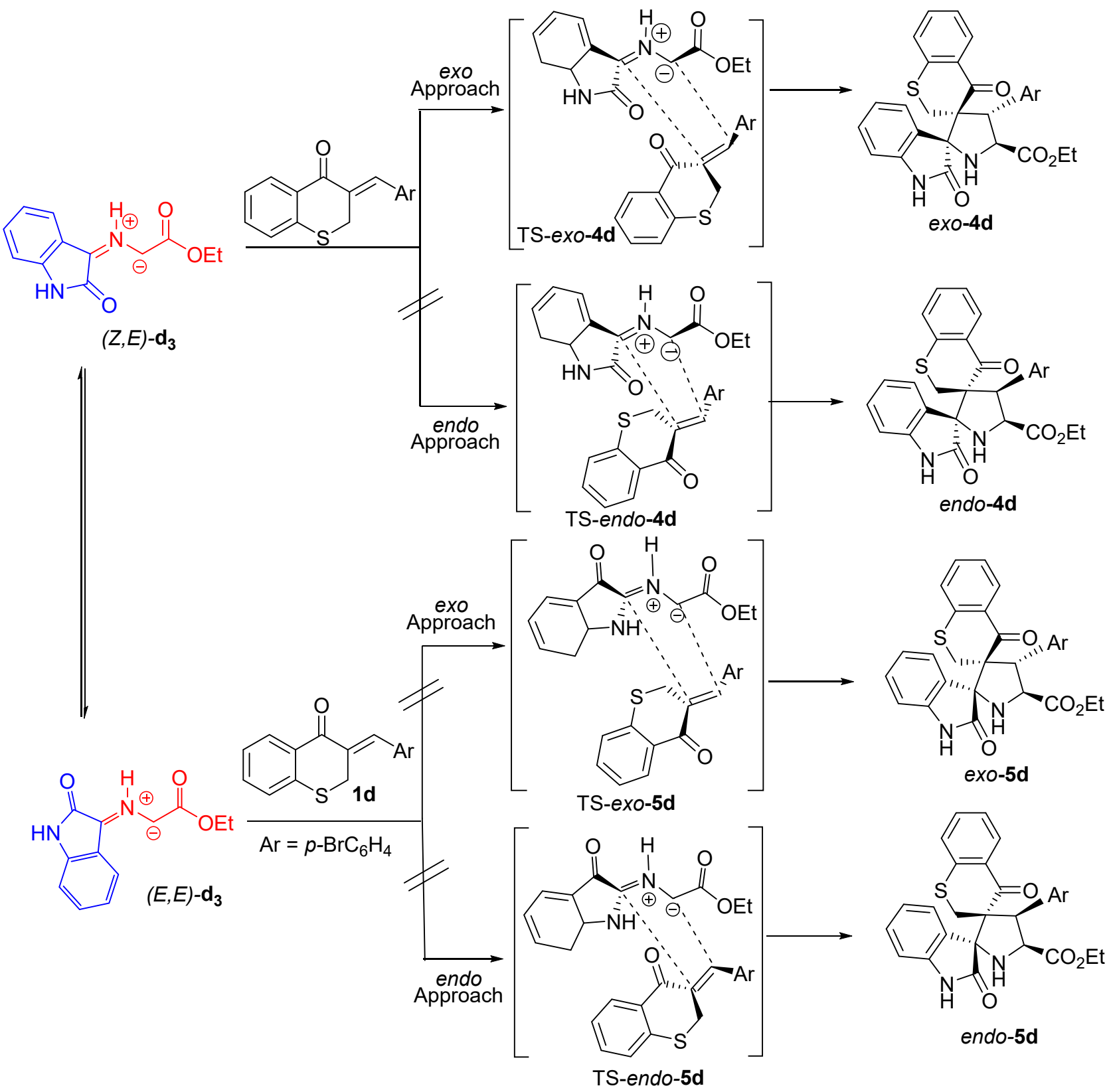

Scheme 2. Proposed mechanism for the regio- and stereoisomeric 1,3-dipolar cycloaddition reaction of dipolarophile $\mathbf{1 d}$ with azomethine ylide $\mathbf{d}_{\mathbf{3}}$.

In line with our previous study [55], condensation of a glycine ethyl ester and isatin, or acenaphthenequinone, followed by a [1,2]-prototropic sequence furnishes $(E, E)$ and $(Z, E)$ azomethine ylides are the two most stable isomers. Note that the subsequent 1,3-dipolar cycloaddition of these intermediates can a priori occur through both endo-TS and exo- 
TSs (Scheme 2). Kinetic and thermodynamic calculations of the Gibbs free energy $(\Delta G)$, enthalpy $(\Delta H)$, and entropy $(\Delta S)$, corresponding to all possible isomeric pathways of the reaction and relative energies for the TSs, are summarized in Table 3.

Table 3. Difference in the Gibbs free energies $\left(\Delta \mathrm{G}\right.$, in $\left.\mathrm{kcal} \mathrm{mol}^{-1}\right)$, enthalpies $\left(\Delta \mathrm{H}\right.$, in kcal mol$\left.{ }^{-1}\right)$ entropies $\left(\Delta S\right.$, in cal $\left.\mathrm{K}^{-1} \mathrm{~mol}^{-1}\right)$, and electronic energies $\left(\Delta \mathrm{U}\right.$, in $\left.\mathrm{kcal} \mathrm{mol}^{-1}\right)$ for TSs and products calculated at the $\omega \mathrm{B} 97 \mathrm{xd} / 6-31 \mathrm{G}(\mathrm{d}, \mathrm{p})$ level of theory.

\begin{tabular}{ccccc}
\hline & $\boldsymbol{\Delta} \mathbf{G}$ & $\boldsymbol{\Delta} \mathbf{H}$ & $\boldsymbol{\Delta} \mathbf{S}$ & $\boldsymbol{\Delta}$ \\
\hline TS-exo-4d & 0.4 & -17.6 & -50.9 & -16.9 \\
TS-endo-4d & 2.0 & 15.4 & -48.9 & -14.7 \\
TS-exo-5d & 15.1 & -3.6 & -52.7 & -2.9 \\
TS-endo-5d & 14.9 & -0.3 & -42.7 & 0.4 \\
exo-4d & -21.8 & -42.4 & -58.1 & -41.7 \\
endo-4d & -14.6 & -34.8 & 57.0 & -34.2 \\
exo-5d & -16.8 & -37.9 & -59.5 & -37.2 \\
endo-5d & -16.3 & -36.2 & -56.3 & -35.5 \\
\hline
\end{tabular}

The analysis of the four located transition states reveals that TS-exo-4d, corresponding to the exo-approach between the $(E)$-p-bromobenzylidenethiochromanone $1 \mathbf{d}$ and the $(Z, E)$ dipole, presents the lowest barriers with a $\Delta \mathrm{G}$ value of $0.4 \mathrm{kcal} \mathrm{mol}^{-1}$, favoring the formation of the observed exo-4d regioisomer. Moreover, $\Delta \mathrm{G}$ values indicate that the product exo$4 \mathrm{~d}$, identified as the sole product is more stable $\left(\Delta \mathrm{G},-21.8 \mathrm{kcal} \mathrm{mol}^{-1}\right)$ than the other theoretical stereoisomers endo- $\mathbf{4 d}$, exo-5d, and endo-5d. Thus, the spiroadduct $\mathbf{4 d}$ is kinetically and thermodynamically preferred, which agrees well with our experimental observations.

\subsection{Biological Evaluation of the Synthesized Compounds}

\subsubsection{Antimicrobial Activity}

The dispiropyrrolidine derivatives 4 and 9 were evaluated for their antibacterial activity against an assortment of five Gram-positive bacteria (Bacillus subtilis ATCC 6633, Staphylococcus epidermidis C11232, Staphylococcus aureus ATCC 29213, Staphylococcus aureus ATCC 25923, and Enterococcus faecalis ATCC 29212) and four Gram-negative bacteria (Escherichia coli ATCC 25922, Klebsiella pneumoniae ATCC 4352, Salmonella enterica 800390, and Pseudomonas aeruginosa ATCC 9023). The antifungal activity of the synthesized compounds was also investigated against Candida albicans ATCC 90028, Candida glabrata ATCC 90030, and Candida krusei ATCC 6258. As references, to evaluate and to compare the potency of the tested compounds under the same conditions, the antibiotics Amoxicillin (AMX) and Ampicillin (AMP) were chosen as antibacterial agents. Macrocyclic Amphotericin B was used as antifungal reference.

The in vitro antimicrobial activity of the novel dispiropyrrolidines has been assessed by the determination of the minimal inhibitory concentration (MIC) using the microdilution method, as described by Rattan [61]. The results are summarized in Tables 4 and 5.

Most of the screened compounds show variable antibacterial activities ranging from poor to excellent against Gram-positive and Gram-negative bacteria with MIC values in the range of 32-250 $\mathrm{gg} / \mathrm{mL}$. As shown in Table 4, compounds $4 \mathbf{a}-\mathbf{e}$ exhibit, in most cases, interesting antibacterial potential. Compounds $4 \mathbf{a}-\mathbf{d}$ displayed the highest activity $(\mathrm{MIC}=32 \mu \mathrm{g} / \mathrm{mL}$ ) towards B. subtilus and S. epidermis compared to the reference antibiotics Amoxicillin ( $\mathrm{MIC}=64 \mu \mathrm{g} / \mathrm{mL}$ ) and Ampicillin ( $\mathrm{MIC}=78 \mu \mathrm{g} / \mathrm{mL}$ ).

Moreover, all these compounds were found to be more active than the standard drugs Amoxicillin $(\mathrm{MIC}=64 \mu \mathrm{g} / \mathrm{mL})$ and Ampicillin $(\mathrm{MIC}=78 \mu \mathrm{g} / \mathrm{mL})$ against the screened Gram-negative bacteria with MIC values ranging from 64 to $125 \mu \mathrm{g} / \mathrm{mL}$. For the series $\mathbf{9 a}-\mathbf{h}$, results presented in Table 4 indicate that the most performant derivatives exhibit an inferior activity compared to the spirocompounds of series 4 . They show only a poor to moderate activity with MIC values ranging from 64 to $250 \mu \mathrm{g} / \mathrm{mL}$. It is noteworthy that 
compounds $4 a, 4 b, 4 d$, and $4 \mathbf{e}$, with MIC value of $64 \mu \mathrm{g} / \mathrm{mL}$, perform with an excellent activity, up to four times higher towards P. aeruginosa than Amoxicillin (MIC $=256 \mu \mathrm{g} / \mathrm{mL}$ ).

Table 4. MIC values (in $\mu \mathrm{g} / \mathrm{mL}$ ) of the target compounds 4 and $\mathbf{9}$ against Gram-positive and Gramnegative bacteria activities.

\begin{tabular}{|c|c|c|c|c|c|c|c|c|c|}
\hline \multirow[b]{2}{*}{ Comp. } & \multicolumn{5}{|c|}{ Gram Positive Bacteria } & \multicolumn{4}{|c|}{ Gram Negative Bacteria } \\
\hline & $\begin{array}{c}\text { B. subtilis } \\
\text { ATCC } 6633\end{array}$ & $\begin{array}{l}\text { S. epider- } \\
\text { midis } \\
\text { CI1232 }\end{array}$ & $\begin{array}{l}\text { S. aureus } \\
\text { ATCC } \\
29213\end{array}$ & $\begin{array}{l}\text { S. aureus } \\
\text { ATCC } \\
25923\end{array}$ & $\begin{array}{c}\text { E. faecalis } \\
\text { ATCC } \\
29212\end{array}$ & $\begin{array}{c}\text { E. coli } \\
\text { ATCC } \\
25922\end{array}$ & $\begin{array}{l}\text { K. pneumo- } \\
\text { niae } \\
\text { АТСС } 4352\end{array}$ & $\begin{array}{c}\text { S. enterica } \\
800390\end{array}$ & $\begin{array}{l}\text { P. aeruginosa } \\
\text { ATCC } 9023\end{array}$ \\
\hline $4 a$ & 32 & 32 & 64 & 32 & 32 & 125 & 64 & 64 & 64 \\
\hline $4 b$ & 32 & 32 & 64 & 32 & 32 & 125 & 64 & 64 & 125 \\
\hline $4 c$ & 32 & 32 & 64 & 64 & 32 & 125 & 64 & 64 & 64 \\
\hline $4 d$ & 32 & 32 & 64 & 64 & 32 & 125 & 64 & 64 & 64 \\
\hline $4 e$ & 32 & 32 & 64 & 32 & 64 & 250 & 64 & 125 & 64 \\
\hline $9 a$ & 125 & 250 & 125 & 125 & 125 & 250 & 250 & 550 & 250 \\
\hline $9 b$ & 125 & 250 & 250 & 250 & 125 & 125 & 125 & 550 & 125 \\
\hline $9 c$ & 125 & 125 & 125 & 250 & 64 & 250 & 64 & 550 & 125 \\
\hline $9 d$ & 64 & 64 & 500 & 125 & 64 & 125 & 64 & 550 & 125 \\
\hline $9 e$ & 125 & 250 & 125 & 125 & 64 & 250 & 64 & 550 & 125 \\
\hline $9 f$ & 64 & 64 & 125 & 125 & 125 & 125 & 250 & 550 & 250 \\
\hline $9 g$ & 64 & 64 & 125 & 125 & 125 & 125 & 500 & 500 & 500 \\
\hline $9 \mathrm{~h}$ & 64 & 64 & 125 & 125 & 250 & 250 & 500 & 500 & 500 \\
\hline $\mathbf{A M X}^{\mathrm{a}}$ & 64 & - & - & - & 1 & 256 & 256 & - & 256 \\
\hline $\mathbf{A M P}^{\mathrm{a}}$ & - & 78 & 50 & 50 & - & - & - & 100 & - \\
\hline
\end{tabular}

a Positive control.

Table 5. Antifungal activity of synthesized compounds 4 and 9 (MIC was determined in $\mu \mathrm{g} / \mathrm{mL}$ ).

\begin{tabular}{cccc}
\hline Compound & $\begin{array}{c}\text { Candida albicans } \\
\text { ATCC 90028 }\end{array}$ & $\begin{array}{c}\text { Candida glabrata } \\
\text { ATCC 90030 }\end{array}$ & $\begin{array}{c}\text { Candida krusei } \\
\text { ATCC 6258 }\end{array}$ \\
\hline 4a & 64 & 64 & 64 \\
4b & 64 & 64 & 64 \\
4c & 64 & 64 & 64 \\
4d & 64 & 32 & 32 \\
4e & 64 & 64 & 64 \\
9a & 250 & 250 & 250 \\
9b & 250 & 125 & 125 \\
9c & 125 & 125 & 125 \\
9d & 125 & 125 & 250 \\
9e & 500 & 500 & 500 \\
9f & 125 & 250 & 125 \\
9g & 250 & 125 & 250 \\
9h & 125 & 250 & 250 \\
\hline Amphotericin B & 500 & 500 & 500 \\
\hline
\end{tabular}

a Positive control.

The compounds $\mathbf{9 d}$ and $\mathbf{9 f}-\mathbf{h}(\mathrm{MIC}=64 \mu \mathrm{g} / \mathrm{mL})$ are more potent than Amoxicillin $(\mathrm{MIC}=78 \mu \mathrm{g} / \mathrm{mL})$ against $S$. epidermis and exhibit an activity against $B$. subtilus similar to that of the reference antibiotic Ampicillin (MIC $=64 \mu \mathrm{g} / \mathrm{mL}$ ). The results of antifungal screening (Table 5) reveal that compound 9e was the only one exhibiting an activity comparable to that of reference antifungal Amphotericin B (MIC $=500 \mu \mathrm{g} / \mathrm{mL})$ against the tested fungi.

The other synthesized compounds of series 4 were found to be more active than the standard drug with MICs ranging between 32-500 $\mu \mathrm{g} / \mathrm{mL}$. Notably, compound 4d was found to be the most potent antifungal agent (MIC $=32 \mu \mathrm{g} / \mathrm{mL}$ ) towards C. krusei and C. glabrata compared to the reference antifungal Amphotericin B (MIC $=500 \mu \mathrm{g} / \mathrm{mL})$.

In contrast, compounds $\mathbf{9 a}-\mathbf{h}$ were revealed to be less active than their analogues, 4, against the three screened yeasts with MIC values ranging from of $125-500 \mu \mathrm{g} / \mathrm{mL}$. 


\subsubsection{Structure-Activity Relationship (SAR)}

Another aim of these studies was to analyze qualitatively and quantitatively the structure-activity relationships (SAR) of our dispiropyrrolidines. As described in the literature, spiropyrrolidine derivatives are known to be excellent antimicrobial agents $[8,62,63]$. For the first screening of the in vivo antimicrobial results, it is clearly outlined that the presence of a thiochromanone moiety in spiropyrrolidines $\mathbf{4 a}-\mathbf{e}$, independently of the nature of the para-substituent attached on the phenyl ring, greatly influences the inhibitory activity against all of the tested bacterial and fungal strains in comparison to their analogues containing a chromanone moiety $\mathbf{9 a}-\mathbf{h}$. These results conclude the importance of the introduction of the thiochromanone moiety to improve the activity of spiropyrrolidines. Compounds 4a-e especially feature a broad-spectrum bacterial and antifungal action and exerted the more potent antimicrobial effect as compared to the rest of the synthesized compounds.

Concerning the series $\mathbf{9 a}-\mathbf{d}$, bearing an oxindole core, it is interesting to note that the introduction of an electron-withdrawing bromine substituent (9d) at the para position of the aromatic cycle of the chromanone, caused an increase of the antibacterial activity towards B. subtilus, S. epidermis, E.coli, K. pneumoniae, and P. aeruginosa. In contrast, the introduction of an electron-donating group, such as a methyl (9b) or methoxy group (9c), decreased the activity potency or retained it against the same bacteria.

Among the spiropyrrolidines incorporating an acenaphthylene-1(2H)-one core $\mathbf{9 e}-\mathbf{h}$, compound 9e, with an unsubstituted phenyl ring, is the most active one against K. pneumoniae and P. aeruginosa. Compounds $9 \mathrm{f}(4-\mathrm{MePh}), \mathbf{9 g}(4-\mathrm{MeOPh})$, and $\mathbf{9 h}(4-\mathrm{BrPh})$ are found to exert a superior antibacterial effect against B. subtilus and S. epidermis. The inductive or mesomeric electronic effects exerted by these groups allow, probably, each bacterium to interact in its own specific way with the corresponding compounds.

According to the antifungal activity results and based on the study of the structureactivity relationships (SAR), we noticed that compounds containing a thiochromanone ring, 4a-e, display significant antifungal activity against all the tested fungal strains, superior to those of the chromanone-grafted spiropyrrolidines, $\mathbf{9 a}-\mathbf{h}$, and the reference antifungal Amphotericin B. In addition, the compound $\mathbf{4 d}$ is the most potent one against $C$. krusei and C. glabrata. This finding shows that the presence of a bromine atom in para position of the phenyl group of chromanone seems to be responsible for the enhanced activity.

\subsection{DFT Computational Studies}

\subsubsection{Optimized Molecular Structures and HOMO-LUMO Energies}

The ground state geometric optimization of spiropyrrolidines $\mathbf{4 a -} \mathbf{f}$ and $\mathbf{9 a}-\mathbf{h}$ was carried out in the gas phase with the $\omega$ B97xd functional [58] and the standard 6-31g(d,p) basis set in Gaussian 16 package [64]. The simulated electron densities distribution of the FMOs, including both HOMO and LUMO orbitals of all compounds, are indicated in Table S2 (see Supporting Information). Frontier molecular orbital energies and chemical reactivity descriptor values of the optimized geometries are summarized in Tables 6 and 7.

Table 6. The HOMO, LUMO energies and molecular descriptors of compounds 4a-f.

\begin{tabular}{|c|c|c|c|c|c|c|}
\hline \multirow{2}{*}{ Compound } & $\mathrm{E}_{\text {номо }}$ & $\mathrm{E}_{\text {LUMO }}$ & \multirow{2}{*}{$\Delta \mathrm{E}_{\text {gap }}$} & $\eta$ & $\mu$ & $\omega$ \\
\hline & & & & \multicolumn{3}{|c|}{$(e V)$} \\
\hline $4 a$ & -7.463 & -5.502 & 1.961 & 0.981 & -6.483 & 21.422 \\
\hline $4 b$ & -7.462 & -5.501 & 1.961 & 0.981 & -6.482 & 21.415 \\
\hline $4 c$ & -7.459 & -5.494 & 1.965 & 0.983 & -6.477 & 21.338 \\
\hline $4 d$ & -7.462 & -5.507 & 1.955 & 0.978 & -6.485 & 21.501 \\
\hline $4 e$ & -7.497 & -5.860 & 1.637 & 0.819 & -6.679 & 27.234 \\
\hline $4 f$ & -7.496 & -5.860 & 1.636 & 0.818 & -6.678 & 27.259 \\
\hline
\end{tabular}


Table 7. The HOMO, LUMO energies and molecular descriptors of compounds $\mathbf{9 a}-\mathbf{h}$.

\begin{tabular}{|c|c|c|c|c|c|c|}
\hline \multirow{2}{*}{ Compound } & $\mathrm{E}_{\text {HOMO }}$ & $\mathrm{E}_{\text {LUMO }}$ & \multirow{2}{*}{$\Delta \mathrm{E}_{\text {gap }}$} & $\eta$ & $\mu$ & $\omega$ \\
\hline & \multicolumn{2}{|c|}{$(\mathrm{eV})$} & & \multicolumn{3}{|c|}{$(\mathrm{eV})$} \\
\hline $9 a$ & -8.386 & -5.499 & 2.887 & 1.444 & -6.943 & 16.692 \\
\hline $9 b$ & -8.387 & -5.497 & 2.890 & 1.445 & -6.942 & 16.675 \\
\hline $9 c$ & -8.380 & -5.492 & 2.888 & 1.444 & -6.936 & 16.658 \\
\hline $9 d$ & -8.387 & -5.499 & 2.888 & 1.444 & -6.943 & 16.692 \\
\hline $9 e$ & -8.449 & -5.875 & 2.574 & 1.287 & -7.162 & 19.928 \\
\hline $9 f$ & -8.447 & -5.874 & 2.573 & 1.287 & -7.161 & 19.922 \\
\hline $9 g$ & -8.426 & -5.874 & 2.552 & 1.276 & -7.150 & 20.032 \\
\hline $9 \mathrm{~h}$ & -8.448 & -5.878 & 2.570 & 1.285 & -7.163 & 19.964 \\
\hline
\end{tabular}

The molecular frontier orbitals provide important clues to the chemical reactivity of molecules. The FMOs energy gap describes the charge transfer character from HOMO to LUMO within the studied compounds. The HOMO energy represents the tendency of a molecule to donate electrons, while the LUMO energy indicates the ability to accept electrons [65].

Thus, increasing the HOMO energy and decreasing the LUMO energy of the ligand lead to large intermolecular interactions with the LUMO and the HOMO of the receptor. The extent of these stabilizing interactions between ligand-receptor interacting orbitals correlates with the HOMO-LUMO energy gap. The softest molecules are determined with small energy gap values $\left(\Delta \mathrm{E}_{\mathrm{gap}}=\mathrm{E}_{\mathrm{LUMO}}-\mathrm{E}_{\mathrm{HOMO}}\right)$ and are also identified as more stable and, hence, more reactive, according to Pearson's "Hard and Soft Acids and Bases" principle [66].

As shown from Table 4, the HOMO and LUMO electron-density of spiropyrrolidines 4a-f is delocalized on the thiochromanone ring except in $4 \mathbf{e}$ and $\mathbf{4 f}$, where the electrondensity of the LUMO, which indicates the electrophilic attack site, is mainly distributed over the acenaphtene nucleus. For the designed compounds $\mathbf{9 a}-\mathbf{f}$, the HOMO orbital was found to be distributed all over the pyrrolidine ring and isatin or acenaphtenequinone nucleus. However, the LUMO orbitals are dispersed over the chromanone ring in the series of compounds $\mathbf{9 a}-\mathbf{d}$ and on the acenaphtenequinone ring in compounds $\mathbf{9 e}-\mathbf{h}$. Interestingly, the spiropyrrolidines $\mathbf{4 a}-\mathbf{f}$ bearing a thiochroman-4-one moiety show smaller energy gap values, ranging between 1.636 and $1.965 \mathrm{eV}$, compared to spiropyrrolidine derivatives 9a-h featuring a chroman-4-one scaffold ( $\Delta \mathrm{E}_{\text {gap }}$ in the range of 2.552 and $\left.2.890 \mathrm{eV}\right)$. Consequently, compounds $\mathbf{4 a}-\mathbf{f}$ are the most reactive, compared to compounds $\mathbf{9 a}-\mathbf{h}$, which show the lowest reactivity (the most chemically stable). These results may explain the higher biological activity of compounds $4 \mathbf{a}-\mathbf{f}$, providing a good match with the experimental antifungal and antibacterial data.

The reactivity descriptors, based on the analysis of the electronic chemical potential $(\mu)$, the chemical hardness $(\eta)$, and the electrophilicity index $(\omega)$, provide useful insight into the chemical reactivity and stability of the molecules. The chemical potential describes the electron transfer capacity that occurs in the molecule in the fundamental state and the propensity of electrons to escape from an equilibrium system, whereas the chemical hardness indicates the resistance to charge transfer $[67,68]$. As shown in Table 4, compounds 4a-f showed higher chemical potential (ranging from -6.477 to $-6.679 \mathrm{eV}$ ) and lower hardness values (in the range of 0.818 to $0.983 \mathrm{eV}$ ). Consequently, the spiropyrrolidines $4 \mathbf{a}-\mathbf{f}$ are softer and more reactive than the chromanone-grafted spiropyrrolidines $\mathbf{9 a}-\mathbf{h}$. The biological activity of compounds $\mathbf{4 a}-\mathbf{f}$ can, thus, be affected by the strong charge transfer interaction. The electrophilicity $(\omega)$, which defines the tendency of molecules to attract electrons [69], is also superior in the series of spiropyrrolidines $\mathbf{4 a - d}$. Hence, the bioactivity of these compounds may be explained by the ability of the biological target to receive electrons from neighboring molecules, which may be important for stabilization of the active site. 


\subsubsection{Molecular Electrostatic Potential (MEP)}

The MEP has emerged as a powerful approach in drug design and molecular biology to understand the intermolecular interactions between molecules and their biological receptors (proteins, enzymes). The MEP is applied to explore the chemical affinity and most likely binding modes with a molecular receptor, thus providing insight into the structure activity relationship of bioactive compounds. MEP-mapped surfaces inform on the chemical reactivity of the molecules and provide a reliable description of the charge distributions in a pictorial form. They also indicate the most likely electrophilic and nucleophilic reactive sites, polarization of molecules, as well as hydrogen bonding interactions [70-73].

The sites related to the polar and nonpolar regions of the molecule are visualized by color variations. Electrophilic regions are indicated by blue coloration (electron-deficient regions), while nucleophilic regions are shown in red color (electron-rich regions). The electrostatic potential maps of the selected compounds $4 a, 4 e, 9 c, 9 d, 9 e$, and $9 \mathrm{f}$ are shown in Figure 7.

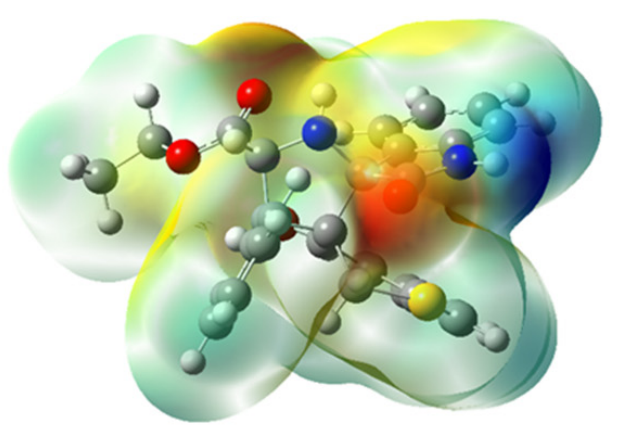

$4 \mathbf{a}$

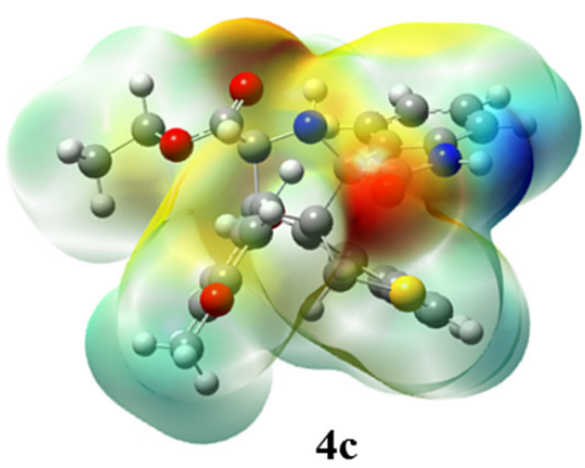

$4 c$

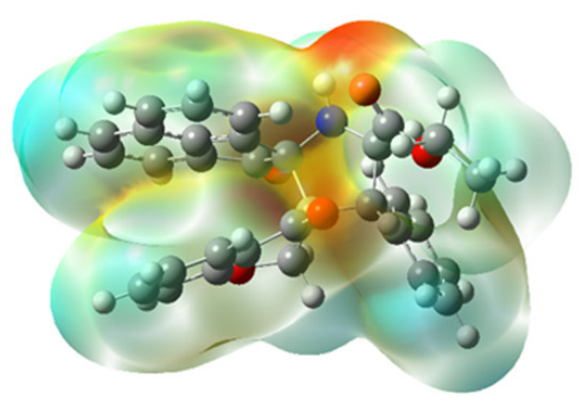

$9 \mathbf{e}$

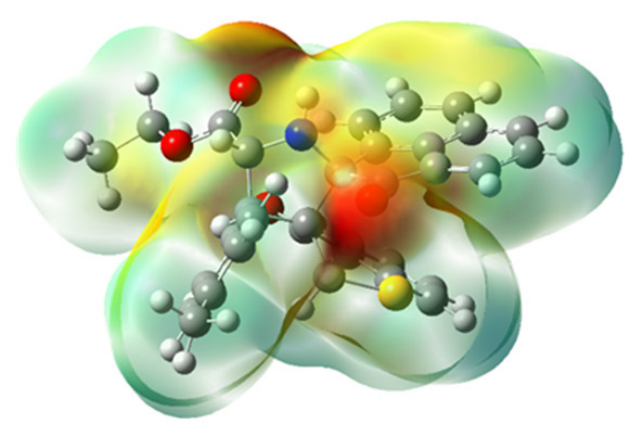

$4 e$
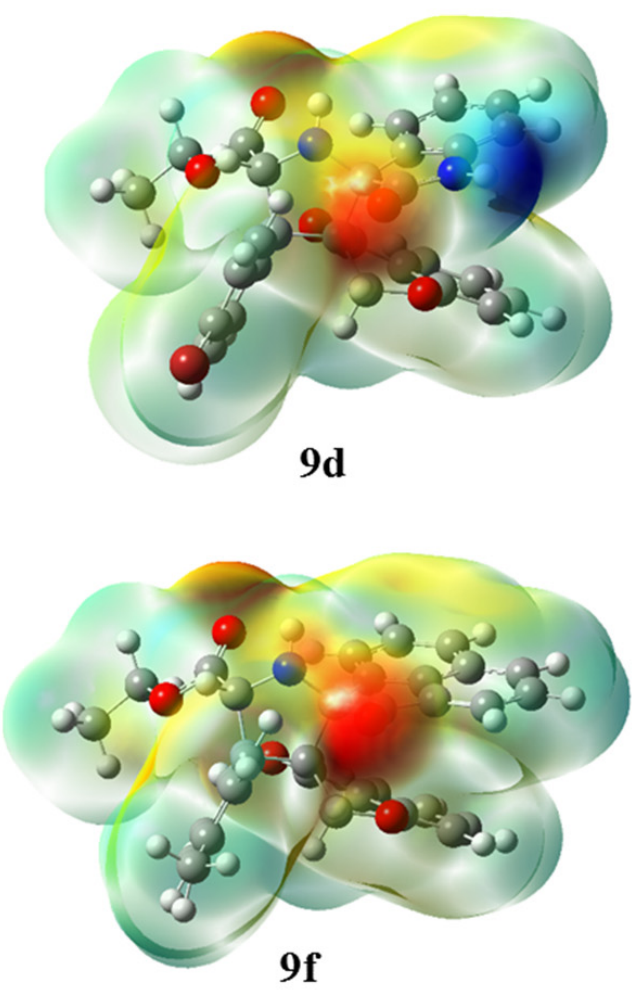

Figure 7. Molecular electrostatic potential (MEP) formed by mapping of the total density over the electrostatic potential for compounds $4 \mathrm{a}, \mathbf{4 e}, \mathbf{4 c}, \mathbf{9 d}, \mathbf{9 e}$, and $9 \mathrm{f}$. 


\subsection{Drug-Likeness Analysis}

Analyzing the physicochemical properties of the developed drug hits is a crucial step to analyze and determine their drug-likeness potential. In this regard, quantitative structure-activity relationships (QSAR) descriptors, which can be calculated by means of a variety of software packages, may be a very useful tool. In this work, we evaluated the drug-likeness potential of the six selected compounds (4a, 4d, 4e, 9c, 9d, and 9e) through computing various QSAR descriptors, according to the Lipinski rule of five [74] and the Veber's parameters (Table 8) [75].

Table 8. Results of Lipinski and Veber rules for the tested compounds.

\begin{tabular}{ccccccc}
\hline Compound & $\mathbf{4 d}$ & $\mathbf{9 d}$ & $\mathbf{9 e}$ & $\mathbf{9 c}$ & $\mathbf{4 a}$ & $\mathbf{4 e}$ \\
\hline lip_acc & 6 & 7 & 6 & 8 & 6 & 5 \\
lip_don & 3 & 3 & 2 & 3 & 3 & 2 \\
lip_druglike & 1 & 1 & 1 & 1 & 1 & 0 \\
lip_violation & 1 & 1 & 1 & 0 & 0 & 2 \\
logP(o/w) & 4.46 & 3.83 & 4.81 & 2.99 & 3.67 & 5.75 \\
Weight & 564.48 & 548.41 & 504.56 & 499.54 & 485.58 & 534.66 \\
TPSA & 89.08 & 98.31 & 86.28 & 107.54 & 89.08 & 77.05 \\
logS & -8.03 & -7.06 & -7.95 & -6.02 & -6.94 & -9.4 \\
vol & 478.5 & 464.88 & 476 & 464.88 & 451.25 & 507.5 \\
b_rotN & 4 & 4 & 4 & 5 & 4 & 4 \\
mr & 14.37 & 13.8 & 14.32 & 13.68 & 13.61 & 15.34 \\
a_hyd & 27 & 26 & 29 & 26 & 26 & 31 \\
\hline
\end{tabular}

Molecular weights of the compounds range from 485.58 to 564.48 Da. Derivatives 4a and 9c, having molecular weights less than $500 \mathrm{Da}$, obey the first Lipinski rule for effective and safe drug delivery. Lipinski's second rule stipulates that drug-like compounds should not possess more than five hydrogen bond donating groups. All of the six compounds comply with this rule. Hydrogen bond accepting groups in all compounds are in the range of 5-8, which is less than ten, thus also meeting Lipinski's third rule. The determined $\log \mathrm{P}$ value was 2.99-5.75. All compounds, therefore, satisfy Lipinski's rule regarding $\log \mathrm{P}$ with a value inferior to five. An exception is compound $4 \mathbf{e}$, whose $\log \mathrm{P}$ value exceeds five. Compounds $4 \mathbf{a}$ and $9 \mathrm{c}$ showed zero Lipinski violations, compounds $\mathbf{4 d}$, 9d, and 9e violated one rule, while compound $4 \mathbf{e}$ violated two rules and, thus, failed to show a drug-likeness potential (Table 8). Veber's parameters, such as molar refractivity (mr) and total polar surface area (TPSA), demonstrate the polarizability of the compounds and suggest their oral bioavailability [75]. The mr values of the six compounds did not fall in the recommended range of $40-130 \mathrm{~cm}^{3} / \mathrm{mol}$, however, this was offset by their TPSA value, which was not superior to 140 for any of the compounds. This suggests, for derivatives, an appreciable oral bioavailability. Besides, the number of rotatable bonds is four or five, which is inferior to 10. Except for compound 4e, which failed in drug-likeness parameters, some additional parameters, such as solubility, van der Waals volume, and number of hydrophobic atoms (a-hyd) were found to be in the acceptable range of -6 to $-8,451-478$, and 26-31, respectively.

\section{Materials and Methods}

\subsection{Apparatus and General Information}

The ${ }^{1} \mathrm{H}$ NMR spectra were recorded at 300 and $400 \mathrm{MHz}$ using a Bruker Avance 300 or Bruker Avance III-400 machine (Rheinstetten, Germany). The chemical shifts were recorded in ppm relative to TMS and with the solvent resonance as the internal standard. Data were reported as follows: chemical shift, multiplicity ( $\mathrm{bs}=$ broad singlet, $\mathrm{s}=$ singlet, $\mathrm{d}=\mathrm{doublet}$, $\mathrm{t}=$ triplet, $\mathrm{m}=$ multiplet), coupling constants $(\mathrm{Hz})$, integration. ${ }^{13} \mathrm{C}\left\{{ }^{1} \mathrm{H}\right\} \mathrm{NMR}$ data were collected at 75 or $100 \mathrm{MHz}$ with complete proton decoupling with the solvent resonance as the internal standard. Elemental analyses were performed on a Perkin Elmer 2400 Series II 
Elemental CHNS analyzer (Waltham, MA, USA). Materials: thin-layer chromatography (TLC): TLC plates (Merck, silica gel 60 F254 0.2 mm, $200 \times 200$ nm) (Darmstadt, Germany); substances were detected using UV light at $254 \mathrm{~nm}$.

\subsection{General Procedure for Preparation of Cycloadducts 4 and 9}

A mixture of 3-arylidenethiochroman-4-ones/3-arylidenecroman-4-ones (1 mmol), ethyl glycinate hydrochloride $(1 \mathrm{mmol}) \mathbf{2}$, isatin 3 or acenaphthenequinone $\mathbf{3}^{\prime}(1 \mathrm{mmol})$, and $\mathrm{Et}_{3} \mathrm{~N}(1 \mathrm{mmol})$ in acetonitrile $(5 \mathrm{~mL})$ was heated under reflux for $2 \mathrm{~h}$. After completion of the reaction (TLC monitoring), the solvent was removed under vacuum. The residue was chromatographed on silica gel employing ethylacetate-cyclohexane $(3: 7 v / v)$ as eluent to obtain the pure products 4 and 9 .

3.2.1. $\left(2 S^{*}, 3 R^{*}, 4^{*} S, 5 S^{*}\right)$-Spiro[2,3']-oxindole-spiro[3,3"] thiochroman-4"-one-4-phenyl-5carboxyethoxypyrrolidine (4a)

White solid; Yield: $(387 \mathrm{mg}, 80 \%) ; \mathrm{mp}\left({ }^{\circ} \mathrm{C} \pm 2\right)=184{ }^{\circ} \mathrm{C}$; IR (KBr) v: 3267, 2918, 1723, 1692, 1650, 1183, $749 \mathrm{~cm}^{-1},{ }^{1} \mathrm{H} \mathrm{NMR}\left(300 \mathrm{MHz}, \mathrm{CDCl}_{3}\right) \delta_{\mathrm{H}}: 1.10\left(\mathrm{t}, J=7.2 \mathrm{~Hz}, 3 \mathrm{H}, \mathrm{CH}_{3}(\mathrm{ester})\right), 2.73(\mathrm{~d}$, $\left.J=14,4 \mathrm{~Hz}, 1 \mathrm{H}, \mathrm{H}-2^{\prime \prime}\right), 3.42$ (d, $\left.J=14.4 \mathrm{~Hz}, 1 \mathrm{H}, \mathrm{H}-2^{\prime \prime}\right), 4.12-4.2\left(\mathrm{~m}, 2 \mathrm{H}, \mathrm{CH}_{2}\right.$ (ester)), 5.02 (d, $J=10.5 \mathrm{~Hz}, 1 \mathrm{H}, \mathrm{H}-4), 5.14$ (d, J = $10.5 \mathrm{~Hz}, 1 \mathrm{H}, \mathrm{H}-5), 6.59-6.62$ (m, 1H, Ar-H), 6.72-6.74 (m, 1H, Ar-H), 6.81-6.84 (m, 1H, Ar-H), 6.97-7.05 (m, 2H, Ar-H), 7.09-7.12 (m, 2H, Ar-H), 7.28-7.40 (m, 3H, Ar-H), 7.56-7.58 (m, 1H, Ar-H), 8.14-8.17 (m, 1H, Ar-H), 8.18 (bs, 1H, $\left.\mathrm{H}-1^{\prime}\right) ;{ }^{13} \mathrm{C} \mathrm{NMR}\left(75 \mathrm{MHz}, \mathrm{CDCl}_{3}\right) \delta_{\mathrm{C}}: 13.9,33.6,56.7,61.2,61.7,62.6,71.8,110.0,122.0,124.7$, 125.6,126.0, 126.6, 127.6,128.5, 126.6, 130.1, 130.7, 132.6, 136.2, 141.4, 142.2, 171.2, 177.4, 194.1. Anal. Calcd for $\mathrm{C}_{28} \mathrm{H}_{24} \mathrm{~N}_{2} \mathrm{O}_{4} \mathrm{~S}$ : C, 69.40; H, 4.99; N, 5.78\%. Found: C, 69.07; H, 4.95; N, $5.79 \%$.

3.2.2. $\left(2 S^{*}, 3 R^{*}, 4^{*} S, 5 S^{*}\right)$-Spiro[2,3']-oxindole-spiro[3,3"] thiochroman-4"'-one-4-( $p$-methyl phenyl)-5-carboxyethoxypyrrolidine $(4 \mathrm{~b})$

White solid; Yield: (423 $\mathrm{mg}, 85 \%) ; \mathrm{mp}\left({ }^{\circ} \mathrm{C} \pm 2\right)=218{ }^{\circ} \mathrm{C}$; IR $(\mathrm{KBr})$ v: 3323, 2969, 1714, 1700, 1658, 1195, $759 \mathrm{~cm}^{-1} ;{ }^{1} \mathrm{H} \operatorname{NMR}\left(300 \mathrm{MHz}, \mathrm{CDCl}_{3}\right) \delta_{\mathrm{H}}: 1.13(\mathrm{t}, J=6.9 \mathrm{~Hz}, 3 \mathrm{H}$, $\mathrm{CH}_{3}$ (ester)), 2.69 (s, 3H, CH $\mathrm{CH}_{3}, 2.74$ (d, J = $\left.14.1 \mathrm{~Hz}, 1 \mathrm{H}, \mathrm{H}-2^{\prime \prime}\right), 3.39$ (d, J = 14.4 Hz, 1H, H-2"), 4.11-4.19 (m, 2H, $\mathrm{CH}_{2}$ (ester)), 4.95 (d, $\left.J=10.2 \mathrm{~Hz}, 1 \mathrm{H}, \mathrm{H}-4\right), 5.05$ (d, J = $\left.10.5 \mathrm{~Hz}, 1 \mathrm{H}, \mathrm{H}-5\right)$, 6.55-6.60 (m, 1H, Ar-H), 6.68-6.81 (m, 3H, Ar-H), 6.89-7.32 (m, 4H, Ar-H), 7.41-7.43 (m, 2H, Ar-H), 8.09-8.14 (m, 2H, Ar-H); $\left.{ }^{13} \mathrm{C} \mathrm{NMR} \mathrm{(75} \mathrm{MHz,} \mathrm{CDCl}_{3}\right) \delta_{\mathrm{C}}: 13.5,21.0,32.2,54.6,55.4$, $60.6,61.9,63.1,72.0,109.5,113.1,121.5,124.6,126.6,129.0,129.4,131.3,132.0,132.3,141.5$, 141.6, 158.4, 178.1, 192.4. Anal. Calcd for $\mathrm{C}_{29} \mathrm{H}_{26} \mathrm{~N}_{2} \mathrm{O}_{4} \mathrm{~S}: \mathrm{C}, 69.86 ; \mathrm{H}, 5.26 ; \mathrm{N}, 5.62 \%$. Found: C, 69.53; H, 5.30; N, 5.63\%.

3.2.3. $\left(2 S^{*}, 3 R^{*}, 4^{*} S, 5 S^{*}\right)-\left[2,3^{\prime}\right]$-oxindole-spiro[3,3"] thiochroman-4"-one-4-(pmethoxyphenyl)-5-carboxyethoxypyrrolidine (4c)

White solid; Yield: (401 mg, 78\%); $\mathrm{mp}\left({ }^{\circ} \mathrm{C} \pm 2\right)=168{ }^{\circ} \mathrm{C}$; IR (KBr) v: 3270, 2925, 1734, 1697, 1655, 1194, $764 \mathrm{~cm}^{-1},{ }^{1} \mathrm{H}$ NMR $\left(300 \mathrm{MHz}, \mathrm{CDCl}_{3}\right) \delta_{\mathrm{H}}: 1.12(\mathrm{t}, J=7.2 \mathrm{~Hz}, 3 \mathrm{H}$, $\mathrm{CH}_{3}$ (ester)), 2.53 (d, J = 14.1 Hz, 1H, H-2"), 3.39 (d, J = 14.1 Hz, 1H, H-2"), $3.80\left(\mathrm{~s}, 3 \mathrm{H}, \mathrm{OCH}_{3}\right)$, 4.12-4.19 (m, 2H, CH 2 (ester)), 4.93 (d, J = $10.5 \mathrm{~Hz}, 1 \mathrm{H}, \mathrm{H}-4), 4,99$ (d, J = $10.5 \mathrm{~Hz}, 1 \mathrm{H}, \mathrm{H}-5)$, 6.57-6.72 (m, 2H, Ar-H), 6.80-6.90 (m, 4H, Ar-H), 6.96-7.10 (m, 3H, Ar-H), 7.46-7.48 (m, 2H, Ar-H), 8.13-8.15 (m, 1H, Ar-H), 8.22 (bs, $\left.1 \mathrm{H}, \mathrm{H}-1^{\prime}\right) ;{ }^{13} \mathrm{C} \mathrm{NMR}\left(75 \mathrm{MHz}, \mathrm{CDCl}_{3}\right) \delta_{\mathrm{C}}$ : 13.5, 33.2, 54.6, 56.0, 60.5, 61.4, 62.6, 71.5, 109.2, 113.4, 121.4, 124.1, 125.4, 125.9, 126.0, 128.0, $128.8,130.1,130.3,130.6,131.9,140.8,141.7,158.4,171.3,177.8,193.8$. Anal. Calcd for $\mathrm{C}_{29} \mathrm{H}_{26} \mathrm{~N}_{2} \mathrm{O}_{4} \mathrm{~S}: \mathrm{C}, 67.69 ; \mathrm{H}, 5.09 ; \mathrm{N}, 5.44 \%$. Found: $\mathrm{C}, 67.36 ; \mathrm{H}, 5.13 ; \mathrm{N}, 5.45 \%$.

3.2.4. $\left(2 S^{*}, 3 R^{*}, 4^{*} S, 5 S^{*}\right)-\left[2,3^{\prime}\right]$-oxindole-spiro[3,3"] thiochroman-4"'-one-4-(pbromophenyl)-5-carboxyethoxypyrrolidine (4d)

White solid; Yield: $(490 \mathrm{mg}, 87 \%) ; \operatorname{mp}\left({ }^{\circ} \mathrm{C} \pm 2\right)=221{ }^{\circ} \mathrm{C}$; IR (KBr) v: 3277, 2922, 1744, 1708, 1660, 1178, $754 \mathrm{~cm}^{-1} ;{ }^{1} \mathrm{H}$ NMR $\left(300 \mathrm{MHz}, \mathrm{CDCl}_{3}\right) \delta_{\mathrm{H}}: 1.12(\mathrm{t}, J=7.2 \mathrm{~Hz}, 3 \mathrm{H}$, $\mathrm{CH}_{3}$ (ester)), $2.70\left(\mathrm{~d}, \mathrm{~J}=14.4 \mathrm{~Hz}, 1 \mathrm{H}, \mathrm{H}-2^{\prime \prime}\right), 3.32\left(\mathrm{~d}, 1 \mathrm{H}, \mathrm{J}=14.4 \mathrm{~Hz}, 1 \mathrm{H}, \mathrm{H}-2^{\prime \prime}\right), 4.13-4.21$ (m, 2H, $\mathrm{CH}_{2}$ (ester)), 4.93 (d, $\left.J=10.2 \mathrm{~Hz}, 1 \mathrm{H}, \mathrm{H}-4\right), 5.11$ (d, $\left.J=10.5 \mathrm{~Hz}, 1 \mathrm{H}, \mathrm{H}-5\right), 6.53-6.58$ (m, 
1H, Ar-H), 6.74-6.92 (m, 3H, Ar-H), 6.96-7.15(m, 3H, Ar-H), 7.49-7.59 (m, 4H, Ar-H), 8.13-8.14 (m, 1H, Ar-H), $8.16\left(\mathrm{bs}, 1 \mathrm{H}, \mathrm{H}-1^{\prime}\right) ;{ }^{13} \mathrm{C} \mathrm{NMR}\left(75 \mathrm{MHz}, \mathrm{CDCl}_{3}\right) \delta_{\mathrm{C}}: 14.0,33.5,55.5$, 61.0, 61.7, 62.4, 71.7, 110.4, 121.9, 122.1, 124.3, 125.0, 126.8, 130.0, 130.5, 130.7, 131.8, 131.9, 133.0, 135.0, 141.9, 142.3, 170.4, 176.3, 194.2. Anal. Calcd for $\mathrm{C}_{28} \mathrm{H}_{23} \mathrm{BrN}_{2} \mathrm{O}_{4} \mathrm{~S}: \mathrm{C}, 59.69 ; \mathrm{H}$, $4.11 ; \mathrm{N}, 4.97 \%$. Found: C, 59.58; H, 4.26; N, 5.01\%.

3.2.5. $\left(2 S^{*}, 3 R^{*}, 4^{*} S, 5 S^{*}\right)$-Spiro[2, $\left.2^{\prime}\right]$-acenaphthene-1'-one-spiro[3,3']thiochroman-4"-one-4( $p$-methylphenyl)-5-carboxyethoxypyrrolidine (4e)

White solid; Yield: $(469 \mathrm{mg}, 88 \%) ; \mathrm{mp}\left({ }^{\circ} \mathrm{C} \pm 2\right)=128^{\circ} \mathrm{C}$; IR (KBr) v: 3291, 3054, 1724, 1709, 1661, 1188, 783, $749 \mathrm{~cm}^{-1}$; ${ }^{1} \mathrm{H}$ NMR $\left(300 \mathrm{MHz}, \mathrm{CDCl}_{3}\right) \delta_{\mathrm{H}}: 1.11(\mathrm{t}, J=7.2 \mathrm{~Hz}, 3 \mathrm{H}$, $\mathrm{CH}_{3}$ (ester)), $2.35\left(\mathrm{~s}, 3 \mathrm{H}, \mathrm{CH}_{3}\right), 2.70\left(\mathrm{~d}, J=14.1 \mathrm{~Hz}, 1 \mathrm{H}, \mathrm{H}-2{ }^{\prime \prime}\right), 3.30(\mathrm{~d}, J=14.4 \mathrm{~Hz}, 1 \mathrm{H}$,

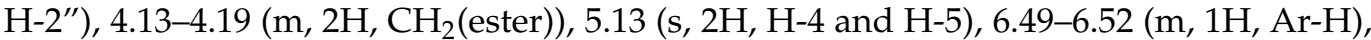
6.94-6.98 (m, 2H, Ar-H), 7.15-7.27 (m, 4H, Ar-H), 7.46-7.48 (m, 2H, Ar-H), 7.59-7.61 (m, $1 \mathrm{H}, \mathrm{Ar}-\mathrm{H}), 7.66-7.71(\mathrm{~m}, 1 \mathrm{H}, \mathrm{Ar}-\mathrm{H}), 7.39-7.99(\mathrm{~m}, 2 \mathrm{H}, \mathrm{Ar}-\mathrm{H}), 8.05-8.08(\mathrm{~m}, 1 \mathrm{H}, \mathrm{Ar}-\mathrm{H}) ;{ }^{13} \mathrm{C}$ NMR $\left(75 \mathrm{MHz}, \mathrm{CDCl}_{3}\right) \delta_{\mathrm{C}}: 14.0,21.0,33.5,56.3,61.3,62.7,63.1,74.7,122.2,122.7,124.7$, 125.6, 126.6, 127.6, 128.1, 129.3, 129.7, 130.3, 130.5, 130.9, 131.3, 131.9, 132.4, 132.7, 135.6, 137.3, 141.7, 171.3, 194.0, 201.8. Anal. Calcd for $\mathrm{C}_{33} \mathrm{H}_{27} \mathrm{NO}_{4} \mathrm{~S}: \mathrm{C}, 74.28 ; \mathrm{H}, 5.10 ; \mathrm{N}, 2.62 \%$. Found: C, 74.06; H, 5.14; N, 2.60\%.

3.2.6. $\left(2 S^{*}, 3 R^{*}, 4^{*} S, 5 S^{*}\right)$-Spiro[2, $\left.2^{\prime}\right]$-acenaphthene-1'-one-spiro[3,3"]thiochroman-4"-one-4(p-methoxyphenyl)-5-arboxyethoxypyrrolidine (4f)

White solid; Yield: $(494 \mathrm{mg}, 90 \%) ; \mathrm{mp}\left({ }^{\circ} \mathrm{C} \pm 2\right)=114{ }^{\circ} \mathrm{C}$; IR $(\mathrm{KBr})$ v: 3282, 2990, $1718,1705,1662,1186,779,736 \mathrm{~cm}^{-1} ;{ }^{1} \mathrm{H}$ NMR $\left(300 \mathrm{MHz} \mathrm{CDCl}_{3}\right) \delta_{\mathrm{H}}: 1.09(\mathrm{t}, J=7.2 \mathrm{~Hz}$, $3 \mathrm{H}, \mathrm{CH}_{3}$ (ester)), $2.68\left(\mathrm{~d}, J=14.4 \mathrm{~Hz}, 1 \mathrm{H}, \mathrm{H}-2^{\prime \prime}\right), 3.30\left(\mathrm{~d}, J=14.4 \mathrm{~Hz}, 1 \mathrm{H}, \mathrm{H}-2^{\prime \prime}\right), 3.79$ (s, $\left.3 \mathrm{H}, \mathrm{OCH}_{3}\right), 4.1-4.16\left(\mathrm{~m}, 2 \mathrm{H}, \mathrm{CH}_{2}\right.$ (ester) $), 5.01(\mathrm{~d}, J=10.8 \mathrm{~Hz}, 1 \mathrm{H}, \mathrm{H}-4), 5.11(\mathrm{~d}, J=10.8$ $\mathrm{Hz}, 1 \mathrm{H}, \mathrm{H}-5), 6.47-6.48$ (m, 1H, Ar-H), 6.87-6.94 (m, 3H, Ar-H), 7.12-7.26 (m, 2H, Ar-H), 7.48-7.56 (m, 3H, Ar-H), 7.62-7.72 (m, 2H, Ar-H), 7.88-7.94 (m, 2H, Ar-H), 8.02-8.05 (m, $1 \mathrm{H}, \mathrm{Ar}-\mathrm{H}) ;{ }^{13} \mathrm{C}$ NMR $\left(75 \mathrm{MHz}, \mathrm{CDCl}_{3}\right) \delta_{\mathrm{C}}: 14.0,33.5,55.0,56.3,61.3,62.7,63.1,74.7,122.2$, 122.7, 124.7, 125.6, 126.6, 127.6, 128.1, 129.3, 129.7, 130.3, 130.5, 130.9, 131.3, 131.9, 132.4, 132.7, 135.6, 136.0, 137.3, 171.3, 194.0, 201.8. Anal. Calcd for $\mathrm{C}_{33} \mathrm{H}_{27} \mathrm{NO}_{5} \mathrm{~S}: \mathrm{C}, 72.11 ; \mathrm{H}, 4.95$; $\mathrm{N}, 2.55 \%$. Found: C, $72.44 ; \mathrm{H}, 4.99 ; \mathrm{N}, 2.57 \%$.

3.2.7. $\left(2 S^{*}, 3 R^{*}, 4^{*} S, 5 S^{*}\right)$-Spiro[2,3']-oxindole-spiro[3,3"] chroman-4"-one-4-phenyl-5carboxyethoxypyrrolidine (9a)

White solid; Yield: $(402 \mathrm{mg}, 86 \%) \mathrm{mp}\left({ }^{\circ} \mathrm{C} \pm 2\right)=182{ }^{\circ} \mathrm{C}$; IR (KBr) v: 3331, 2974, 1726, $1701,1682,759 \mathrm{~cm}^{-1} ;{ }^{1} \mathrm{H} \mathrm{NMR}\left(300 \mathrm{MHz}, \mathrm{CDCl}_{3}\right) \delta_{\mathrm{H}}: 1.00\left(\mathrm{t}, J=7.2 \mathrm{~Hz}, 3 \mathrm{H}, \mathrm{CH}_{3}(\mathrm{ester})\right.$ ), $3.46\left(\mathrm{~d}, J=12.3 \mathrm{~Hz}, 1 \mathrm{H}, \mathrm{H}-2^{\prime \prime}\right), 4.01-4.10\left(\mathrm{~m}, 2 \mathrm{H}, \mathrm{CH}_{2}\right.$ (ester)), $4.72(\mathrm{~d}, J=10.5 \mathrm{~Hz}, 1 \mathrm{H}$, H-4); 4.75 (d, J = 12.3 Hz, 1H, H-2"), 4.98 (d, J = $10.5 \mathrm{~Hz}, 1 \mathrm{H}, \mathrm{H}-5), 6.47-6.50$ (m, 1H, Ar-H), 6.72-6.78 (m, 2H, Ar-H), 6.92-6.98 (m, 2H, Ar-H), 7.13-7.15 (m, 1H, Ar-H), 7.23-7.30 $(\mathrm{m}, 3 \mathrm{H}, \mathrm{Ar}-\mathrm{H}), 7.49-7.52(\mathrm{~m}, 2 \mathrm{H}, \mathrm{Ar}-\mathrm{H}), 7.61-7.64(\mathrm{~m}, 1 \mathrm{H}, \mathrm{Ar}-\mathrm{H}), 8.17$ (bs, $\left.1 \mathrm{H}, \mathrm{H}-1^{\prime}\right) ;{ }^{13} \mathrm{C}$ NMR $\left(75 \mathrm{MHz}, \mathrm{CDCl}_{3}\right) \delta_{\mathrm{C}}: 13.9,53.0,61.1,61.6,63.1,71.3,71.5,109.3,116.7,120.8,121.1$, $122.2,125.8,126.6,127.7,128.5,129.3,129.5,134.9,135.3,140.8,161.1,171.6,179.2,191.7$. Anal. Calcd for $\mathrm{C}_{28} \mathrm{H}_{24} \mathrm{~N}_{2} \mathrm{O}_{5}$ : C, 71.78; H, 5.16; N, 5.98\%. Found: C, 71.60; H, 5.06; N, 5.89\%.

3.2.8. $\left(2 S^{*}, 3 R^{*}, 4^{*} S, 5 S^{*}\right)$-Spiro[2, $\left.3^{\prime}\right]$-oxindole-spiro[3,3"] chroman-4"-one-4-( $p$ methylphenyl)-5-carboxyethoxypyrrolidine $(9 \mathbf{b})$

Yellow solid; Yield: $(366 \mathrm{mg}, 76 \%) ; \mathrm{mp}\left({ }^{\circ} \mathrm{C} \pm 2\right)=226^{\circ} \mathrm{C}$; IR (KBr) v: 3281, 3002, 1716, $1695,1675,764 \mathrm{~cm}^{-1},{ }^{1} \mathrm{H}$ NMR $\left(400 \mathrm{MHz} \mathrm{CDCl}_{3}\right) \delta_{\mathrm{H}}: 1.10\left(\mathrm{t}, J=7.1 \mathrm{~Hz}, 3 \mathrm{H}, \mathrm{CH}_{3}(\right.$ ester $)$ ), $2.30\left(\mathrm{~s}, 3 \mathrm{H}, \mathrm{CH}_{3}\right), 3.54$ (d, $\left.J=12.4 \mathrm{~Hz}, 1 \mathrm{H}, \mathrm{H}-2^{\prime \prime}\right), 4.10-4.16\left(\mathrm{~m}, 2 \mathrm{H}, \mathrm{CH}_{2}\right.$ (ester)), 4.78 (d, $J=10.8 \mathrm{~Hz}, 1 \mathrm{H}, \mathrm{H}-4), 4.84\left(\mathrm{~d}, J=12.4 \mathrm{~Hz}, 1 \mathrm{H}, \mathrm{H}-2^{\prime \prime}\right), 5.02(\mathrm{~d}, J=10.8 \mathrm{~Hz}, 1 \mathrm{H}, \mathrm{H}-5), 6.59(\mathrm{~d}$, $J=8.1 \mathrm{~Hz}, 2 \mathrm{H}, \mathrm{Ar}-\mathrm{H}), 6.80-6.69(\mathrm{~m}, 2 \mathrm{H}, \mathrm{Ar}-\mathrm{H}), 7.02-6.92(\mathrm{~m}, 2 \mathrm{H}, \mathrm{Ar}-\mathrm{H}), 7.21-7.10(\mathrm{~m}, 3 \mathrm{H}$, Ar-H), $7.39(\mathrm{~d}, J=7.8 \mathrm{~Hz}, 2 \mathrm{H}, \mathrm{Ar}-\mathrm{H}), 7.62(\mathrm{dd}, J=7.9 \mathrm{~Hz}, J=1.5 \mathrm{~Hz}, 1 \mathrm{H}, \mathrm{Ar}-\mathrm{H}), 8.36$ (bs, $1 \mathrm{H}$, $\left.\mathrm{H}-1^{\prime}\right) ;{ }^{13} \mathrm{C}$ NMR $\left(100 \mathrm{MHz}, \mathrm{CDCl}_{3}\right) \delta_{\mathrm{C}}: 14.0,21.1,52.7,61.2,61.5,63.2,71.3,71.5,109.3,116.7$, 121.1, 122.2, 125.8, 127.7, 129.2, 129.5, 131.7, 135.4, 137.3, 161.1, 171.7, 179.3, 191.8. Anal. Calcd for $\mathrm{C}_{29} \mathrm{H}_{26} \mathrm{~N}_{2} \mathrm{O}_{5}$ : C, 71.78; $\mathrm{H}, 5.16 ; \mathrm{N}, 5.98 \%$. Found: $\mathrm{C}, 71.60 ; \mathrm{H}, 5.06 ; \mathrm{N}, 5.89 \%$. 
3.2.9. $\left(2 S^{*}, 3 R^{*}, 4^{*} S, 5 S^{*}\right)$-Spiro[2, $\left.3^{\prime}\right]$-oxindole-spiro[3,3"] 3 chroman-4"-one-4-(pmethoxyphenyl)-5-carboxyethoxypyrrolidine (9c)

Yellow solid; Yield: $(418 \mathrm{mg}, 84 \%) ; \mathrm{mp}\left({ }^{\circ} \mathrm{C} \pm 2\right)=228^{\circ} \mathrm{C}$; IR (KBr) v: 3315, 2985, 1721, $1688,1674,748 \mathrm{~cm}^{-1},{ }^{1} \mathrm{H}$ NMR $\left(300 \mathrm{MHz}, \mathrm{CDCl}_{3}\right) \delta_{\mathrm{H}}: 1.13\left(\mathrm{t}, J=7.1 \mathrm{~Hz}, 3 \mathrm{H}, \mathrm{CH}_{3}(\right.$ ester $)$ ), $3.51\left(\mathrm{~d}, J=12.3 \mathrm{~Hz}, 1 \mathrm{H}, \mathrm{H}-2^{\prime \prime}\right), 3.81\left(\mathrm{~s}, 3 \mathrm{H}, \mathrm{OCH}_{3}\right), 4.13-4.19\left(\mathrm{~m}, 2 \mathrm{H}, \mathrm{CH}_{2}\right.$ (ester)), 4.76 $\left(\mathrm{d}, J=12.3 \mathrm{~Hz}, 1 \mathrm{H}, \mathrm{H}-2^{\prime \prime}\right), 4.91(\mathrm{~d}, J=11.1 \mathrm{~Hz}, 1 \mathrm{H}, \mathrm{H}-4), 5.09(\mathrm{~d}, J=11.1 \mathrm{~Hz}, 1 \mathrm{H}, \mathrm{H}-5)$, $6.00(\mathrm{~d}, J=8.3 \mathrm{~Hz}, 1 \mathrm{H}, \mathrm{Ar}-\mathrm{H}), 6.53(\mathrm{t}, J=7.5 \mathrm{~Hz}, 1 \mathrm{H}, \mathrm{Ar}-\mathrm{H}), 6.94-6.71(\mathrm{~m}, 3 \mathrm{H}, \mathrm{Ar}-\mathrm{H}), 7.36$ $(\mathrm{ddd}, J=33.3 \mathrm{~Hz}, J=18.9 \mathrm{~Hz}, J=7.7 \mathrm{~Hz}, 4 \mathrm{H}, \mathrm{Ar}-\mathrm{H}), 7.52(\mathrm{~d}, J=8.1 \mathrm{~Hz}, 1 \mathrm{H}, \mathrm{Ar}-\mathrm{H}), 7.60$ $(\mathrm{t}, J=7.6 \mathrm{~Hz}, 1 \mathrm{H}, \mathrm{Ar}-\mathrm{H}), 7.83(\mathrm{~d}, J=8.1 \mathrm{~Hz}, 1 \mathrm{H}, \mathrm{Ar}-\mathrm{H}), 7.91(\mathrm{~d}, J=7.0 \mathrm{~Hz}, 1 \mathrm{H}, \mathrm{Ar}-\mathrm{H}) ;{ }^{13} \mathrm{C}$ NMR $\left(75 \mathrm{MHz}, \mathrm{CDCl}_{3}\right) \delta_{\mathrm{C}}: 14.0,52.3,55.2,61.2,61.4,63.3,71.2,71.6,109.2 ; 113.9,116.7$, 120.8, 121.1, 122.2, 125.8, 126.4, 126.7, 127.7, 129.5, 135.3, 140.6, 159.0, 161.1, 171.5, 178.8, 191.8. Anal. Calcd for $\mathrm{C}_{29} \mathrm{H}_{26} \mathrm{~N}_{2} \mathrm{O}_{6}: \mathrm{C}, 69.87 ; \mathrm{H}, 5.26 ; \mathrm{N}, 5.62 \%$. Found: $\mathrm{C}, 69.00 ; \mathrm{H}, 5.37 ; \mathrm{N}$, $5.59 \%$.

3.2.10. $\left(2 S^{*}, 3 R^{*}, 4^{*} S, 5 S^{*}\right)$-Spiro[2,3']-oxindole-spiro[3,3"]chroman-4"-one-4-( $p$ bromophenyl)-5-carboxyethoxypyrrolidine (9d)

White solid; Yield: $(514 \mathrm{mg}, 94 \%) ; \mathrm{mp}\left({ }^{\circ} \mathrm{C} \pm 2\right)=234{ }^{\circ} \mathrm{C}$; IR $(\mathrm{KBr}) v: 3323,2969$, 1714,1694, 16969, $749 \mathrm{~cm}^{-1} ;{ }^{1} \mathrm{H}$ NMR $\left(400 \mathrm{MHz}, \mathrm{CDCl}_{3}\right) \delta_{\mathrm{H}}: 1.11(\mathrm{t}, J=7.1 \mathrm{~Hz}, 3 \mathrm{H}$, $\mathrm{CH}_{3}($ ester $\left.)\right), 3.53\left(\mathrm{~d}, J=12.3 \mathrm{~Hz}, 1 \mathrm{H}, \mathrm{H}-2^{\prime \prime}\right), 4.10-4.18\left(\mathrm{~m}, 2 \mathrm{H}, \mathrm{CH}_{2}\right.$ (ester)), $4.77(\mathrm{t}, J=10.7 \mathrm{~Hz}$, $2 \mathrm{H}, \mathrm{H}-4$ and $\left.\mathrm{H}-2^{\prime \prime}\right), 5.00(\mathrm{~d}, J=10.6 \mathrm{~Hz}, 1 \mathrm{H}, \mathrm{H}-5), 6.62-6.50(\mathrm{~m}, 2 \mathrm{H}, \mathrm{Ar}-\mathrm{H}), 6.72(\mathrm{dt}$, $J=28.4 \mathrm{~Hz}, J=7.6 \mathrm{~Hz}, 2 \mathrm{H}, \mathrm{Ar}-\mathrm{H}), 6.98-6.86(\mathrm{~m}, 2 \mathrm{H}, \mathrm{Ar}-\mathrm{H}), 7.21-7.10(\mathrm{~m}, 1 \mathrm{H}, \mathrm{Ar}-\mathrm{H}), 7.42(\mathrm{~m}$, $4 \mathrm{H}, \mathrm{Ar}-\mathrm{H}), 7.62(\mathrm{dd}, J=7.9 \mathrm{~Hz}, J=1.4 \mathrm{~Hz}, 1 \mathrm{H}, \mathrm{Ar}-\mathrm{H}) ; 8.22\left(\mathrm{bs}, 1 \mathrm{H}, \mathrm{H}-1^{\prime}\right) ;{ }^{13} \mathrm{C}$ NMR $(100 \mathrm{MHz}$, $\left.\mathrm{CDCl}_{3}\right) \delta_{\mathrm{C}}: 14.0,52.3,61.3,63.2,71.4,71.5,109.4,116.7,120.7,121.3,121.7,125.8,127.8,129.6$, 131.1, 131.7, 134.2, 135.6, 140.7, 161.1, 171.4, 191.7. Anal. Calcd for $\mathrm{C}_{28} \mathrm{H}_{23} \mathrm{BrN}_{2} \mathrm{O}_{5}$ : C, 61.44; H, $4.24 ;$ N, 5.12\%. Found: C, 61.58; H, 4.16; N, 5.20\%.

3.2.11. $\left(2 S^{*}, 3 R^{*}, 4^{*} S, 5 S^{*}\right)$-Spiro[2, $\left.2^{\prime}\right]$-acenaphthene-1'-one-spiro[3,3"] chroman-4"-one-4phenyl-5-carboxyethoxypyrrolidine (9e)

Yellow solid; (352 mg, 70\%); $\mathrm{mp}\left({ }^{\circ} \mathrm{C} \pm 2\right)=188^{\circ} \mathrm{C}$; IR (KBr) v: 3279, 2911, 1726, 1693, $1674,1193,774,760 \mathrm{~cm}^{-1},{ }^{1} \mathrm{H}$ NMR $\left(400 \mathrm{MHz}, \mathrm{CDCl}_{3}\right) \delta_{\mathrm{H}}: 1.10\left(\mathrm{t}, J=7.1 \mathrm{~Hz}, 3 \mathrm{H}, \mathrm{CH}_{3}(\right.$ ester $\left.)\right)$, $3.47\left(\mathrm{~d}, J=12.3 \mathrm{~Hz}, 1 \mathrm{H}, \mathrm{H}-2^{\prime \prime}\right), 4.13-4.18\left(\mathrm{~m}, 2 \mathrm{H}, \mathrm{CH}_{2}\right.$ (ester)), 4.75 (d, J = 12.3 Hz, 1H, H-2"), $4.90(\mathrm{~d}, J=11.2 \mathrm{~Hz}, 1 \mathrm{H}, \mathrm{H}-4), 5.10(\mathrm{~d}, J=11.1 \mathrm{~Hz}, 1 \mathrm{H}, \mathrm{H}-5), 6.01(\mathrm{~d}, J=7.9 \mathrm{~Hz}, 1 \mathrm{H}, \mathrm{Ar}-\mathrm{H})$, 6.64-6.45 (m, 1H, Ar-H), $6.83(\mathrm{~m}, 1 \mathrm{H}, \mathrm{Ar}-\mathrm{H}), 7.15(\mathrm{~d}, J=7.8 \mathrm{~Hz}, 2 \mathrm{H}, \mathrm{Ar}-\mathrm{H}), 7.47-7.20(\mathrm{~m}, 5 \mathrm{H}$, Ar-H), $7.55(\mathrm{~m}, 2 \mathrm{H}, \mathrm{Ar}-\mathrm{H}), 7.85(\mathrm{~d}, J=8.0 \mathrm{~Hz}, 1 \mathrm{H}, \mathrm{Ar}-\mathrm{H}), 7.93(\mathrm{~d}, J=6.9 \mathrm{~Hz}, 1 \mathrm{H}, \mathrm{Ar}-\mathrm{H}) ;{ }^{13} \mathrm{C}$ NMR $\left(100 \mathrm{MHz}, \mathrm{CDCl}_{3}\right) \delta_{\mathrm{C}}: 14.0,52.2,61.2,62.9,63.2,71.0,74.6,116.1,120.7,120.8,121.5$, $122.2,125.1,127.2$, 127.9, 128.9, 129.2, 129.8, 131.0, 131.5, 131.7, 134.7, 136.9, 137.3, 140.8, 160.0, 171.9, 191.6. Anal. Calcd for $\mathrm{C}_{32} \mathrm{H}_{25} \mathrm{NO}_{5}$ : C, 76.33; H, 5.00; N, 2.78\%. Found: $\mathrm{C}, 76.99$; $\mathrm{H}, 5.06 ; \mathrm{N}, 2.70 \%$.

3.2.12. $\left(2 S^{*}, 3 R^{*}, 4^{*} S, 5 S^{*}\right)$-Spiro[ $\left.2,2^{\prime}\right]$-acenaphthene- $1^{\prime}$-one-spiro[3,3"]chroman-4"-one-4- $(p$ methylphenyl)-5-carboxyethoxypyrrolidine (9f)

Yellow solid; Yield: (377 $\mathrm{mg}, 73 \%) ; \mathrm{mp}\left({ }^{\circ} \mathrm{C} \pm 2\right)=194{ }^{\circ} \mathrm{C}$; IR (KBr) v: 3288, 2898, 1739, 1700, 1667, 1201, 786, $767 \mathrm{~cm}^{-1} ;{ }^{1} \mathrm{H}$ NMR $\left(400 \mathrm{MHz}, \mathrm{CDCl}_{3}\right) \delta_{\mathrm{H}}: 1.10(\mathrm{t}, J=7.1 \mathrm{~Hz}, 3 \mathrm{H}$, $\mathrm{CH}_{3}$ (ester)), $2.30\left(\mathrm{~s}, 3 \mathrm{H}, \mathrm{CH}_{3}\right), 3.47\left(\mathrm{~d}, \mathrm{~J}=12.3 \mathrm{~Hz}, 1 \mathrm{H}, \mathrm{H}-2^{\prime \prime}\right), 4.10-4.17\left(\mathrm{~m}, 2 \mathrm{H}, \mathrm{CH}_{2}\right.$ (ester)), $4.75\left(\mathrm{~d}, J=12.3 \mathrm{~Hz}, 1 \mathrm{H}, \mathrm{H}-2^{\prime \prime}\right), 4.90(\mathrm{~d}, J=11.2 \mathrm{~Hz}, 1 \mathrm{H}, \mathrm{H}-4), 5.10(\mathrm{~d}, J=11.1 \mathrm{~Hz}, 1 \mathrm{H}$, H-5); 6.01 (d, J = 7.9 Hz, 1H, Ar-H), 6.64-6.45 (m, 1H, Ar-H), 6.83 (m, 1H, Ar-H), 7.15 $(\mathrm{d}, J=7.8 \mathrm{~Hz}, 2 \mathrm{H}, \mathrm{Ar}-\mathrm{H}), 7.47-7.20(\mathrm{~m}, 5 \mathrm{H}, \mathrm{Ar}-\mathrm{H}), 7.55(\mathrm{~m}, 2 \mathrm{H}, \mathrm{Ar}-\mathrm{H}), 7.85(\mathrm{~d}, J=8.0 \mathrm{~Hz}$, $1 \mathrm{H}, \mathrm{Ar}-\mathrm{H}), 7.93(\mathrm{~d}, J=6.9 \mathrm{~Hz}, 1 \mathrm{H}, \mathrm{Ar}-\mathrm{H}) ;{ }^{13} \mathrm{C} \mathrm{NMR}\left(100 \mathrm{MHz}, \mathrm{CDCl}_{3}\right) \delta_{\mathrm{C}}: 14.0,21.0,52.7$, 61.2, 63.2, 71.3, 71.5, 109.3, 116.7, 120.1, 122.2, 125.8, 126.6, 127.7, 129.2, 129.5, 131.7, 135.7, $140.8,161.1,171.7,179.3,191.8$. Anal. Calcd for $\mathrm{C}_{33} \mathrm{H}_{27} \mathrm{NO}_{5}$ : C, 76.58; $\mathrm{H}, 5.26 ; \mathrm{N}, 2.71 \%$. Found: C, $76.49 ; \mathrm{H}, 5.38 ; \mathrm{N}, 2.76 \%$. 
3.2.13. $\left(2 S^{*}, 3 R^{*}, 4^{*} S, 5 S^{*}\right)$-Spiro[ $\left.2,2^{\prime}\right]$-acenaphthene-1'-one-spiro[3,3"]chroman-4"-one-4-( $p$ methoxyphenyl)-5-carboxyethoxypyrrolidine $(9 \mathrm{~g})$

Yellow solid; Yield: $(464 \mathrm{mg}, 87 \%) ; \mathrm{mp}\left({ }^{\circ} \mathrm{C} \pm 2\right)=184{ }^{\circ} \mathrm{C}$; IR (KBr) v: 3292, 2899, 1737, 1704, 1677, 1199, 773, $747 \mathrm{~cm}^{-1},{ }^{1} \mathrm{H}$ NMR $\left(400 \mathrm{MHz}, \mathrm{CDCl}_{3}\right) \delta_{\mathrm{H}}: 1.10(\mathrm{t}, J=7.1 \mathrm{~Hz}$, $3 \mathrm{H}, \mathrm{CH}_{3}$ (ester)), 3.55 (d, J = 12.4 Hz, 1H, H-2"), 3.77 (s, 3H, $\left.\mathrm{OCH}_{3}\right), 4.10-4.16(\mathrm{~m}, 2 \mathrm{H}$, $\mathrm{CH}_{2}$ (ester)), $4.76(\mathrm{~d}, J=10.8 \mathrm{~Hz}, 1 \mathrm{H}, \mathrm{H}-4), 4.83\left(\mathrm{~d}, J=12.3 \mathrm{~Hz}, 1 \mathrm{H}, \mathrm{H}-2{ }^{\prime \prime}\right), 4.98(\mathrm{~d}, J=10.8 \mathrm{~Hz}$, $1 \mathrm{H}, \mathrm{H}-5), 6.59(\mathrm{~d}, J=8.0 \mathrm{~Hz}, 2 \mathrm{H}, \mathrm{Ar}-\mathrm{H}), 6.74(\mathrm{dt}, J=15.3 \mathrm{~Hz}, J=7.6 \mathrm{~Hz}, 2 \mathrm{H}, \mathrm{Ar}-\mathrm{H}), 6.87(\mathrm{~d}$, $J=8.5 \mathrm{~Hz}, 2 \mathrm{H}, \mathrm{Ar}-\mathrm{H}), 6.94(\mathrm{~m}, 2 \mathrm{H}, \mathrm{Ar}-\mathrm{H}), 7.17(\mathrm{t}, J=7.3 \mathrm{~Hz}, 1 \mathrm{H}, \mathrm{Ar}-\mathrm{H}), 7.43(\mathrm{~d}, J=8.3 \mathrm{~Hz}$, $2 \mathrm{H}, \mathrm{Ar}-\mathrm{H}), 7.62(\mathrm{~m}, 1 \mathrm{H}, \mathrm{Ar}-\mathrm{H}) ;{ }^{13} \mathrm{C}$ NMR $\left(100 \mathrm{MHz}, \mathrm{CDCl}_{3}\right) \delta_{\mathrm{C}}: 14.0,52.4,55.2,61.2,61.5$, 63.4, 71.4, 71.6, 109.3, 113.9, 116.7, 120.8, 121.1, 122.2, 125.8, 126.6, 126.8, 127.7, 129.4, 130.4, 135.4, 140.8, 159.0, 161.1, 171.1, 171.8, 191.9. Anal. Calcd for $\mathrm{C}_{33} \mathrm{H}_{27} \mathrm{NO}_{6}: \mathrm{C}, 74.28 ; \mathrm{H}, 5.10$; $\mathrm{N}, 2.63 \%$. Found: $\mathrm{C}, 71.35 ; \mathrm{H}, 5.17 ; \mathrm{N}, 2.53 \%$.

3.2.14. $\left(2 S^{*}, 3 R^{*}, 4^{*} S, 5 S^{*}\right)$-Spiro[2, $\left.2^{\prime}\right]$-acenaphthene-1'-one-spiro[3,3"]chroman-4"-one-4-( $p$ bromophenyl)-5-carboxyethoxypyrrolidine (9h)

Yellow solid; Yield: $(425 \mathrm{mg}, 73 \%)$; $\mathrm{mp}\left({ }^{\circ} \mathrm{C} \pm 2\right)=226{ }^{\circ} \mathrm{C}$; IR $(\mathrm{KBr})$ v: 3285, 2883, $1752,1713,1687,1192,792,773 \mathrm{~cm}^{-1} ;{ }^{1} \mathrm{H}$ NMR $\left(400 \mathrm{MHz} \mathrm{CDCl}_{3}\right) \delta_{\mathrm{H}}: 1.11(\mathrm{t}, J=7.1 \mathrm{~Hz}$, $3 \mathrm{H}, \mathrm{CH}_{3}$ (ester)), 3.45 (d, J = 12.2 Hz, 1H, H-2"), 4.12-4.17 (m, 2H, $\mathrm{CH}_{2}$ (ester)); 4.70 (d, $\left.J=12,2 \mathrm{~Hz}, 1 \mathrm{H}, \mathrm{H}-2^{\prime \prime}\right), 4.88(\mathrm{~d}, J=11.1 \mathrm{~Hz}, 1 \mathrm{H}, \mathrm{H}-4), 5.08(\mathrm{~d}, J=11.1 \mathrm{~Hz}, 1 \mathrm{H}, \mathrm{H}-5), 6.01$ $(\mathrm{d}, J=8.3 \mathrm{~Hz}, 1 \mathrm{H}, \mathrm{Ar}-\mathrm{H}), 6.85(\mathrm{~s}, 1 \mathrm{H}, \mathrm{Ar}-\mathrm{H}), 6.57(\mathrm{~s}, 1 \mathrm{H}, \mathrm{Ar}-\mathrm{H}), 7.29(\mathrm{~d}, J=6.8 \mathrm{~Hz}, 1 \mathrm{H}$, Ar-H), 7.38-7.33 (m, 1H, Ar-H), $7.41(\mathrm{~m}, 3 \mathrm{H}, \mathrm{Ar}-\mathrm{H}), 7.49(\mathrm{~d}, J=8.4 \mathrm{~Hz}, 2 \mathrm{H}, \mathrm{Ar}-\mathrm{H}), 7.54$ $(\mathrm{d}, J=8.2 \mathrm{~Hz}, 1 \mathrm{H}, \mathrm{Ar}-\mathrm{H}), 7.66-7.59(\mathrm{~m}, 1 \mathrm{H}, \mathrm{Ar}-\mathrm{H}), 7.89(\mathrm{~m}, 2 \mathrm{H}, \mathrm{Ar}-\mathrm{H}) ;{ }^{13} \mathrm{C}$ NMR $(75 \mathrm{MHz}$, $\left.\mathrm{CDCl}_{3}\right) \delta_{\mathrm{C}}: 14.0,51.8,61.3,63.2,70.9,74.6,116.1,121.0,121.7,122.2,125.2,127.2,127.9,128.0$, $130.8,131.1,131.7,134.9,160.0,171.5,191.4,204.4$. Anal. Calcd for $\mathrm{C}_{32} \mathrm{H}_{24} \mathrm{BrNO}_{5}$ : C, 65.99; H, 4.15; N, 2.40\%. Found: C, 65.90; H, 4.20; N, 2.55\%.

\subsection{Crystal Structure Determinations}

X-ray suitable crystals were grown in $\mathrm{EtOH}$. The crystal structure determination was accomplished on a Bruker D8 Venture four-circle diffractometer using a PHOTON 100 CMOS $(\mathbf{4 a}, \mathbf{9 c})$, or PHOTON II CPAD (4e), detector by Bruker AXS GmbH. X-ray radiation was generated by microfocus source I $\mu S$-Mo $(\lambda=0.71073 \AA$ ) by Incoatec $G m b H$ with HELIOS mirror optics and a single-hole collimator by Bruker AXS GmbH. The crystals of $4 \mathbf{a}, 4 \mathbf{e}$, and $9 \mathrm{c}$ were covered with an inert oil (perfluoropolyalkylether) and mounted on a MicroMount from MiTeGen. For the data collection, the programs APEX 3 Suite (v.2018.7-2), with the integrated programs SAINT (integration) and SADABS (adsorption correction) by BrukerAXS GmbH, were used. The processing and finalization of the crystal structures was done with the program Olex2 [76]. The crystal structure was solved with the ShelXT [77] structure solution program using Intrinsic Phasing and refined with the ShelXL [78] refinement package using Least Squares minimization. The non-hydrogen atoms were refined anisotropically. The $\mathrm{C}$-bound and $\mathrm{H}$ atoms were placed in geometrically calculated positions and each was assigned a fixed isotropic displacement parameter based on a riding-model: $\mathrm{C}-\mathrm{H}=0.95-0.99 \AA$ with $\mathrm{U}_{\text {iso }}(\mathrm{H})=1.5 \mathrm{U}_{\mathrm{eq}}\left(\mathrm{CH}_{3}\right)$ and $1.2 \mathrm{U}_{\text {eq }}\left(\mathrm{CH}_{2}, \mathrm{CH}\right)$ for other hydrogen atoms. The N-bound hydrogen atoms were located in the differenceFourier-map and refined independently. The crystal and structure refinement data of $4 \mathbf{a}, 4 \mathbf{e}$, and $9 \mathrm{c}$ are gathered in Table S3. Crystallographic data for the structures of $4 \mathbf{a}, 4 \mathbf{e}$, and $9 \mathrm{c}$ have been deposited with the Cambridge Crystallographic Data Centre as supplementary publication number 2116000 (4a), 2116001 (4e), and 2115999 (9c). Copies of these data can be obtained, free of charge, on application to CCDC, 12 Union Road, Cambridge, CB2 IEZ, UK; fax: 144-(0)1223-336033 or e-mail: deposit@ccdc.cam.ac.uk.

\subsection{Antimicrobial Activity}

\subsubsection{Determination of the Antibacterial and Antifungal Activity}

Various concentrations of the screened compounds have been used to determine their antimicrobial activity. Both cultures have been set to yield approximately $1 \times 10^{6} \mathrm{CFUmL}^{-1}$ of bacteria or yeast overnight. The minimum inhibitory concentrations (MICs) have been 
determined on brain heart infusion (BHI) agar plates (Bio-Rad, Marne la Coquette, France) by a standard method (Edziri et al., 2012). One milliliter of each of the extracts, previously dissolved in 10\% dimethyl sulfoxide (DMSO), have been mixed for each concentration with $19 \mathrm{~mL}$ of $\mathrm{BHI}$ agar at $40^{\circ} \mathrm{C}$ and poured over Petri dishes. The resulting DMSO concentration was approximately $0.5 \%$. Plates containing only medium, or medium with $0.5 \%$ DMSO, were used as controls to ensure that DMSO did not affect the growth. Standard antibiotics Amoxicillin (AMX) and Ampicillin (AMP), and the antifungal Amphotericin B were used to control the sensitivity of the tested microorganism. After $18 \mathrm{~h}$ of incubation at $37{ }^{\circ} \mathrm{C}$, the MIC was defined as the lowest concentration of the extract inhibiting the visible growth of each microorganism. Each test was carried out in triplicate.

\subsubsection{Microorganisms}

The antibacterial potential of the dispiropyrrolidine derivatives has been investigated against nine microorganisms, namely the Gram-positive Staphylococcus epidermidis (CI1232), Bacillus subtilis (ATCC 6633), Staphylococcus aureus (ATCC 29213), Staphylococcus aureus (ATCC 25923), and Enterococcus faecalis (ATCC 29212) and the Gram-negative rods Escherichia coli (ATCC 25922), Klebsiella pneumoniae (ATCC 4352), Salmonella enterica 800390, and Pseudomonas aeruginosa (ATCC 9023). For the evaluation of the antifungal activity, Candida glabrata (ATCC 90030), Candida albicans (ATCC 90028), and Candida krusei (ATCC 6258) have been used. As references, to evaluate and to compare the potency of the tested compounds under the same conditions, the antibiotics Amoxicillin (AMX) and Ampicillin (AMP) were chosen as antibacterial agents. Macrocyclic Amphotericin B was used as antifungal reference (both of the previously identified bacterial and fungal strains were obtained from the laboratory of Transmissible Diseases and Biologically Active Substances, Faculty of Pharmacy, Tunisia).

\subsection{Computational Methods}

DFT calculations were performed using the Gaussian 16 suite of programs [64]. All geometry optimizations and frequency analyses were carried out using the $\omega$ B97xd functional with the standard 6-31G(d,p) basis set [58]. Vibrational analyses were performed to identify the stationary points as either local minima, or transition states (with one imaginary vibrational mode) on the potential energy surface. Solvent effects were considered using the polarizable continuum model (PCM) with acetonitrile as the solvent medium at a temperature of $355 \mathrm{~K}[59,60]$. The frontier molecular orbitals analysis (FMOs) and molecular electrostatic potential (MEP) surfaces for compounds $\mathbf{4 a - f}$ and $\mathbf{9 a}-\mathbf{h}$ were calculated at the same level of theory and visualized with the graphical interface Gauss View 6 [79] (Gaussian Inc., Wallingford, CT, USA). The chemical reactivity descriptors [80-82] (electronic chemical potential $(\mu)$, electronegativity $(\chi)$, chemical hardness $(\eta)$, and electrophilicity index $\omega)$ are calculated as follows: $\mu=\left(E_{H}+E_{L}\right) / 2 ; \eta=\left(E_{L}-E_{H}\right) / 2 ; \omega=\left(\mu^{2} / 2 \eta\right)$.

\section{Conclusions}

A one-pot three-component 1,3-dipolar cycloaddition reaction of a stabilized azomethine ylide, generated in situ by thermal [1,2]-prototropy of the corresponding iminoesters with (E)-3-arylidene-thiochroman-4-one/chroman-4-one as dipolarophiles afforded the dispiro-oxindole-pyrrolidine-thiochroman-4-ones, $4 \mathbf{a}-\mathbf{f}$ and dispiro-oxindole-pyrrolidinechroman-4-ones, $\mathbf{9 a}-\mathbf{h}$ in satisfactory yields along with high regio- and stereoselectivity. DFT calculations correctly predicted the observed experimental results, evidencing that the reaction is favorable according to kinetic and thermodynamic parameters. The antimicrobial activity of the novel $N$-heterocyclic compounds was examined against different pathogenic bacteria and fungi. According to the antimicrobial activity results, and on the basis of a structure-activity relationships (SAR) study, it follows that compounds $\mathbf{4 a -} \mathbf{d}$ containing a thiochromanone ring display a significant antimicrobial activity against most of the tested bacterial and fungal strains, superior than those of chromanone-grafted spiropyrrolidines $\mathbf{9 a}-\mathbf{h}$. Even the activity of reference antibiotics is outperformed in some cases. Theoretical 
chemical reactivity, taking into account the FMOs and MEP maps, predicted a relatively higher chemical reactivity and softer character of spiropyrrolidines $4 \mathbf{a}-\mathbf{f}$, which seems to have a prominent effect on their higher antimicrobial activity compared to the $\mathbf{9 a}-\mathbf{h}$ derivatives. The predicted absorption, distribution, metabolism, and excretion (ADME) profiles of some derivatives were in line with Lipinski rules. These promising results encourage further study of the antimicrobial activity of these derivatives by measuring their toxicity. Advanced docking studies are in progress and will be published elsewhere.

Supplementary Materials: The following are available online, copies of ${ }^{1} \mathrm{H}$ and ${ }^{13} \mathrm{C}\left\{{ }^{1} \mathrm{H}\right\} \mathrm{NMR}$ spectra of compounds 4 and $\mathbf{9}$, figures of the supramolecular interactions occurring in the crystalline states for $\mathbf{4 a}$ and $\mathbf{9 c}$, DFT and Cartesian coordinates and energies.

Author Contributions: Supervision, methodology, analyses of obtained results, S.B., M.K., A.T., M.A. and A.S.; methodology, analyses of obtained results, writing the manuscript, S.B., M.K., A.T. and A.S.; synthesis, N.C.; X-ray diffraction analysis, M.K., C.S. and L.B.; antimicrobial assays, H.E.; drug-likeness analysis, M.S. and M.A.O.A.; DFT study, A.T. and A.S. All authors have read and agreed to the published version of the manuscript.

Funding: This work was supported by the LR11ES39 Grant from the Ministry of Higher Education and Scientific Research, Tunisia.

Institutional Review Board Statement: Not applicable.

Informed Consent Statement: Not applicable.

Data Availability Statement: The data presented in this study are not available from the authors.

Acknowledgments: The authors are grateful to the Ministry of Higher Education and Scientific Research of Tunisia for financial support (LR11ES39). Computations from the Calcul Quebec and Compute Canada are gratefully acknowledged. M.K. and C.S. acknowledge funding from the CNRS and the Deutsche Forschungsgemeinschaft. The authors would like to thank R. Rashied for her help in collecting the docking data.

Conflicts of Interest: The authors declare no conflict of interest.

Sample Availability: Samples of the compounds are available from the authors.

\section{References}

1. Tong, S.Y.C.; Davis, J.S.; Eichenberger, E.; Holland, T.L.; Fowler, V.G., Jr. Staphylococcus aureus Infections: Epidemiology, Pathophysiology, Clinical Manifestations, and Management. Clin. Microbiol. Rev. 2015, 28, 603-661. [CrossRef] [PubMed]

2. Lowy, F.D. Antimicrobial resistance: The example of Staphylococcus aureus. J. Clin. Investig. 2003, 111, 1265-1273. [CrossRef]

3. WHO. Antimicrobial Resistance. 2018. Available online: www.who.int/news-room/fact-sheets/detail/antimicrobial-resistance (accessed on 30 April 2014).

4. Gurung, R.R.; Maharjan, P.; Chhetri, G.G. Antibiotic resistance pattern of Staphylococcus aureus with reference to MRSA isolates from pediatric patients. Future Sci. OA 2020, 6, FSO464. [CrossRef] [PubMed]

5. Toumi, A.; Boudriga, S.; Hamden, K.; Sobeh, M.; Cheurfa, M.; Askri, M.; Knorr, M.; Strohmann, B.C.L. Synthesis, antidiabetic activity and molecular docking study of rhodanine-substitued spirooxindole pyrrolidine derivatives as novel $\alpha$-amylase inhibitors. Bioorg. Chem. 2021, 106, 104507. [CrossRef]

6. Kumar, R.S.; Almansour, A.I.; Arumugam, N.; Mohammad, F.; Kumar, R.R. In vitro Mechanistic Exploration of Novel Spiropyrrolidine Heterocyclic Hybrids as Anticancer Agents. Front. Chem. 2020, 20, 465. [CrossRef] [PubMed]

7. Singh, G.S.; Desta, Z.Y. Isatins as Privileged Molecules in Design and Synthesis of Spiro-Fused Cyclic Frameworks. Chem. Rev. 2012, 112, 6104-6155. [CrossRef]

8. Arun, Y.; Bhaskar, G.; Balachandran, C.; Ignacimuthu, S.; Perumal, P.T. Facile One-Pot Synthesis of Novel DispirooxindolePyrrolidine Derivatives and Their Antimicrobial and Anticancer Activity Against A549 Human Lung Adenocarcinoma Cancer Cell Line. Bioorg. Med. Chem. Lett. 2013, 23, 1839-1845. [CrossRef] [PubMed]

9. Jossang, A.; Jossang, P.; Hadi, H.A.; Sevenet, T.; Bodo, B. Horsfiline, an oxindole alkaloid from Horsfieldia superba. J. Org. Chem. 1991, 56, 6527-6530. [CrossRef]

10. Kelemen, Á.A.; Satala, G.; Bojarski, A.J.; Keserú, G.M. Spiro[pyrrolidine-3,3'-oxindoles] and Their Indoline Analogues as New 5-HT6 Receptor Chemotypes. Molecules 2017, 22, 2221. [CrossRef]

11. Boudriga, S.; Haddad, S.; Murugaiyah, V.; Askri, M.; Knorr, M.; Strohmann, C.; Golz, C. Three-Component Access to Functionalized Spiropyrrolidine Heterocyclic Scaffolds and Their Cholinesterase Inhibitory Activity. Molecules 2020, 25, 1963. [CrossRef] 
12. Arumugama, N.; Almansoura, A.I.; Kumara, R.S.; Altafa, M.; Padmanabanc, R.; Sureshbabuc, P.; Angamuthuc, G.; Kotreshad, D.; Manohare, T.S.; Venketeshe, S. Spiropyrrolidine/spiroindolizino[6,7-b]indole heterocyclic hybrids: Stereoselective Synthesis, Cholinesterase Inhibitory Activity and Their Molecular Docking Study. Bioorg. Chem. 2018, 79, 64-71. [CrossRef]

13. Wei, A.C.; Ali, M.A.; Yoon, Y.K.; Ismail, R.; Choon, T.S.; Kumar, R.S. A Facile Three-Component [3+2]-Cycloaddition for the Regioselective Synthesis of Highly Functionalised Dispiropyrrolidines Acting as Antimycobacterial Agents. Bioorg. Med. Chem. Lett. 2013, 23, 1383-1386. [CrossRef] [PubMed]

14. Chenera, B.; West, M.L.; Finkelstein, J.A.; Dreyer, G.B. Total synthesis of $( \pm)$-calanolide A, a non-nucleoside inhibitor of HIV-1 reverse transcriptase. J. Org. Chem. 1993, 58, 5605-5606. [CrossRef]

15. Liu, J.; Li, Z.; Tong, P.; Xie, Z.; Zhang, Y.; Li, Y. TMSI-Promoted Vinylogous Michael Addition of Siloxyfuran to 2-Substituted Chromones: A General Approach for the Total Synthesis of Chromanone Lactone Natural Products. J. Org. Chem. 2015, 80, 1632-1643. [CrossRef] [PubMed]

16. Cortés, I.; Cordisco, E.; Kaufman, T.S.; Sortino, M.A.; Svetaz, L.A.; Bracca, A.B.J. First total synthesis of chromanone A, preparation of related compounds and evaluation of their antifungal activity against Candida albicans, a biofilm forming agent. RSC Adv. 2021, 11, 19587-19597. [CrossRef]

17. Cortés, I.; Kaufman, T.S.; Bracca, A.B.J. Short and Efficient First Total Synthesis of the Natural Product Chromanone A, a Chromone Derivative from the Algicolous Marine Fungus Penicillium sp. Chem. Proc. 2020, 1, 8300. [CrossRef]

18. Lee, H.; Yuan, Y.; Rhee, I.; Corson, T.W.; Seo, S.-Y. Synthesis of Natural Homoisoflavonoids Having Either 5,7-Dihydroxy-6methoxy or 7-Hydroxy-5,6-dimethoxy Groups. Molecules 2016, 21, 1058. [CrossRef]

19. Kerste, E.; Harms, K.; Koert, U. Total Synthesis of (-)-Preussochromone D. Org. Lett. 2019, 21, 4374-4377. [CrossRef]

20. Emami, S.; Ghanbarimasir, Z. Recent advances of chroman-4-one derivatives: Synthetic approaches and bioactivities. Eur. J. Med. Chem. 2015, 93, 539-563. [CrossRef]

21. Keri, R.S.; Budagumpi, S.; Pai, R.K.; Balakrishna, R.G. Chromones as a privileged scaffold in drug discovery: A review. Eur. J. Med. Chem. 2014, 8, 340-374. [CrossRef]

22. Kamboj, S.; Singh, R. Chromanone-A Prerogative Therapeutic Scafold: An Overview. Arab. J. Sci. Eng. 2021, 1-37. [CrossRef]

23. Santos, C.M.M.; Silva, A.M.S. Six-membered ring systems: With $O$ and/or S atoms. Prog. Heterocycl. Chem. 2021, 32, 501-563. [CrossRef]

24. Chitti, S.; Pulya, S.; Nandikolla, A.; Patel, T.K.; Kumar, B.K.; Murugesan, S.; Ghosh, B.; Sekhar, K.V.G.C. Design, synthesis and biological evaluation of 7-(5-((substituted-amino)-methyl)-thiophen-2-yl)-spiro-[chroman-2,4'-piperidin]-4-one hydrochloride analogues as anticancer agents. Bioorg. Chem. 2021, 112, 104865. [CrossRef] [PubMed]

25. Chen, H.; Xie, J.; Xing, D.; Wang, J.; Tang, J.; Yi, Z.; Xia, F.; Qiu, W.-W.; Yang, F. Diastereoselective synthesis of 3,3-disubstituted 3-nitro-4-chromanone derivatives as potential antitumor agents. Org. Biomol. Chem. 2019, 17, 1062-1066. [CrossRef]

26. Yurttas, L.; Temel, H.E.; Aksoy, M.O.; Bülbül, E.F.; Çiftçi, G.A. New chromanone derivatives containing thiazoles: Synthesis and antitumor activity evaluation on A549 lung cancer cell line. Drug Dev. Res. 2021, 1-15. [CrossRef]

27. Tuong, T.L.; Do, L.T.M.; Aree, T.; Wonganan, P.; Chavasiri, W. Tetrahydroxanthone-chromanone heterodimers from lichen Usnea aciculifera and their cytotoxic activity against human cancer cell lines. Fitoterapia 2020, 147, 104732. [CrossRef]

28. Yu, G.Y.; Xiao, T. Recent advances in the research of chromone and thiochromone derivatives as antifungal agents. Chin. $J$. Antibiot. 2011, 36, 481-486.

29. Elghareeb, F.H.; Kandil, E.M.; Abou-Elzahab, M.; Abdelmoteleb, M.; Abozeid, M.A. Rigid 3D-spiro chromanone as a crux for efficient antimicrobial agents: Synthesis, biological and computational evaluation. RSC Adv. 2021, 11, 21301-21314. [CrossRef]

30. Yu, J.S.; Li, C.; Kwon, M.; Oh, T.; Lee, T.H.; Kim, D.H.; Ahn, J.S.; Ko, S.-K.; Kim, C.S.; Cao, S.; et al. Herqueilenone A, a unique rearranged benzoquinone-chromanone from the Hawaiian volcanic soil-associated fungal strain Penicillium herquei FT729. Bioorg. Chem. 2020, 105, 104397. [CrossRef]

31. Prakash, O.; Kumar, R.; Sehrawa, R. Synthesis and antibacterial activity of some new 2,3-dimethoxy-3-hydroxy-2-(1-phenyl-3aryl-4-pyrazolyl)chromanones. Eur. J. Med. Chem. 2009, 44, 1763-1767. [CrossRef]

32. Ma, J.; Cao, B.; Chen, X.; Xu, M.; Bi, X.; Guan, P.; Jiang, Y.; Xu, J.; Han, L.; Huang, X. Violacin A, a new chromanone produced by Streptomyces violaceoruber and its anti-inflammatory activity. Bioorg. Med. Chem. Lett. 2018, 28, 947-951. [CrossRef] [PubMed]

33. Castro, H.; Cruz, T.; Amaral, P.A.; Cardoso, P.S.; Alsaffar, A.; Farrell, P.; Tomás, A.M.; Barlow, J.W. Synthesis and evaluation of novel chromanone and quinolinone analogues of uniflorol as anti leishmanial agents. Heliyon 2020, 6, e03614. [CrossRef] [PubMed]

34. Sneha, E.; Jessica, J.; Philip, E.; Shanty, A.A.; Kurup, M.R.P.; Mohanan, P.V. Novel class of mononuclear 2-methoxy-4-chromanones ligated Cu (II), Zn (II), Ni (II) complexes: Synthesis, characterisation and biological studies. Inorg. Chim. Acta 2018, 478, 155-165. [CrossRef]

35. Park, J.; Park, J.-E.; Seo, Y.-W.; Han, J.-S. 5,7-Dimethoxy-3-(2'-hydroxybenzyl)-4-chromanone inhibits $\alpha$-glucosidase in vitro and alleviates postprandial hyperglycemia in diabetic mice. Eur. J. Pharmacol. 2019, 863, 172683. [CrossRef]

36. Gupta, O.; Pradhan, T.; Bhatia, R.; Monga, V. Recent advancements in anti-leishmanial research: Synthetic strategies and structural activity relationships. Eur. J. Med. Chem. 2021, 223, 113606. [CrossRef] [PubMed]

37. Coll, S.; Alhazmi, M.; Amaral, P.A.; Delmas, S.B.; Lamer, A.-C.L.; Barlow, J.W. Synthesis and Evaluation of Novel 2,2Dimethylthiochromanones as Anti-Leishmanial Agents. Molecules 2021, 26, 2209. [CrossRef] [PubMed] 
38. Zhao, P.-L.; Li, J.; Yang, G.-F. Synthesis and insecticidal activity of chromanone and chromone analogues of diacylhydrazines. Bioorg. Med. Chem. 2007, 15, 1888-1895. [CrossRef] [PubMed]

39. Xiao, L.; Yu, L.; Li, P.; Chi, J.; Tang, Z.; Li, J.; Tan, S.; Wang, X. Design, Synthesis, and Bioactivity Evaluation of New Thiochromanone Derivatives Containing a Carboxamide Moiety. Molecules 2021, 26, 4391. [CrossRef]

40. Yu, L.; Chi, J.; Xiao, L.; Li, J.; Tang, Z.; Tan, S.; Li, P. Novel Thiochromanone Derivatives Containing a Sulfonyl Hydrazone Moiety: Design, Synthesis, and Bioactivity Evaluation. Molecules 2021, 26, 2925. [CrossRef] [PubMed]

41. Yu, L.; Xiao, L.; Chi, J.; Tang, Z.; Li, J.; Tan, S.; Li, P. Design, synthesis, and bioactivity evaluation of novel thiochromanone derivatives containing an oxime or oxime ether moiety. J. Heterocycl. Chem. 2021, 58, 2124-2131. [CrossRef]

42. Collado, I.G.; Aleu, J. Metabolism of Antifungal Thiochroman-4-ones by Trichoderma viride and Botrytis cinereal Cristina PinedoRivilla. J. Nat. Prod. 2018, 81, 1036-1040. [CrossRef]

43. Gnanasekaran, K.K.; Benbrook, D.M.; Nammalwar, B.; Thavathiru, E.; Bunce, R.A.; Berlin, K.D. Synthesis and evaluation of second generation Flex-Het scaffolds against the human ovarian cancer A2780 cell line. Eur. J. Med. Chem. 2015, 96, 209-217. [CrossRef] [PubMed]

44. Demirayak, S.; Yurttas, L.; Karaburun, N.G.; Karaburun, A.C.; Kayagil, I. New chroman-4-one/thiochroman-4-one derivatives as potential anticancer agents. Saudi Pharm. J. 2017, 25, 1063-1072. [CrossRef] [PubMed]

45. Hammam, A.E.-F.G.; Fahmy, A.F.M.; Amr, A.-G.E.; Mohamed, A.M. Synthesis of novel tricyclic heterocyclic compounds as potential anticancer agents using chromanone and thiochromanone as synthons. Indian J. Chem. Sect. B 2003, 42, 1985-1993. [CrossRef]

46. Song, J.; Pan, R.; Li, G.; Su, W.; Song, X.; Li, J.; Liu, S. Synthesis and anticancer activities of thiosemicarbazones derivatives of thiochromanones and related scaffolds. Med. Chem. Res. 2020, 29, 630-642. [CrossRef]

47. Nussbaumer, P.; Lehr, P.; Billich, A. 2-Substituted 4-(Thio)chromenone 6-O-Sulfamates: Potent Inhibitors of Human Steroid Sulfatase. J. Med. Chem. 2002, 45, 4310-4320. [CrossRef] [PubMed]

48. Smith, H.J.; Nicholls, P.J.; Simons, C.; Lain, R.L. Inhibitors of steroidogenesis as agents for the treatment of hormone-dependent cancers. Expert Opin. Ther. Pat. 2001, 11, 789-824. [CrossRef]

49. Zimmer, L.; Fournet, G.; Joseph, B.; Guillaumet, G.; Bars, D.L. Carbon-11 labelling of 8\{\{3-[4-(2-[11 C]methoxyphenyl)piperazin-1yl]-2-hydroxypropyl\}oxy\}thiochroman, a presynaptic $5-\mathrm{HT}_{1 \mathrm{~A}}$ receptor agonist, and its in vivo evaluation in anaesthetised rat and in awake cat. Nucl. Med. Biol. 2003, 30, 541-546. [CrossRef]

50. Zhang, D.; Ji, X.; Gao, R.; Wang, H.; Meng, S.; Zhong, Z.; Li, Y.; Jiang, J.; Li, Z. Synthesis and antiviral activities of a novel class of thioflavone and flavonoid analogues. Acta Pharm. Sin. B 2012, 2, 575-580. [CrossRef]

51. Steiner, G.; Schmidt, T.; Kordes, M.; von Deyn, W.; Hofmann, M.; Baumann, E.; Puhl, M.; Heffernan, G.; Culbertson, D.L.; Treacy, M.F. Amino-Substituted Benzo(Hetero)Cyclic Derivatives, Particularly 1-Alkyl-4-Benzo(Hetero)Cyclicsubstituted Piperazines, Useful as Insecticides, Acaricides, and Nematocides, and Their Preparation, Uses, and Compositions. PCT International Application WO 2004080170, 23 September 2004.

52. Subramaniyan, G.; Jayashankaran, J.; Raghunathan, R. Novel Synthesis of N-Methyl Spiropyrrolidines by 1,3-Dipolar Cycloaddition Reaction of Azomethine Ylides. Synth. Commun. 2006, 35, 2189-2193. [CrossRef]

53. Rani, G.U.; Kumar, S.V.; Bharkavi, C.; Menéndez, J.C.; Perumal, S. One-Pot Access to a Library of Dispiro Oxindolepyrrolidine/pyrrolothiazole-thiochromane Hybrids via Three-Component 1,3-Dipolar Cycloaddition Reactions. ACS Comb. Sci. 2016, 18, 337-342. [CrossRef]

54. Haddad, S.; Boudriga, S.; Porzio, F.; Soldera, A.; Askri, M.; Sriram, D.; Yogeeswari, P.; Knorr, M.; Rousselin, Y.; Kubicki, M.M. Synthesis of Novel Dispiropyrrolothiazoles by Three-Component 1,3-Cipolar Cycloaddition and Evaluation of Their Antimycobacterial Activity. RSC Adv. 2014, 4, 59462-59471. [CrossRef]

55. Haddad, S.; Boudriga, S.; Akhaja, T.N.; Raval, J.P.; Porzio, F.; Soldera, A.; Askri, M.; Knorr, M.; Rousselin, Y.; Kubicki, M.M.; et al. A Strategic Approach to the Synthesis of Functionalized Spirooxindole Pyrrolidine Derivatives: In vitro Antibacterial, Antifungal, Antimalarial and Antitubercular studies. New J. Chem. 2015, 39, 520-528. [CrossRef]

56. Mhiri, C.; Boudriga, S.; Askri, M.; Knorr, M.; Sriram, D.; Yogeeswari, P.; Nana, F.; Golz, C.; Strohmanni, C. Design of Novel Dispirooxindolopyrrolidine and Dispirooxindolopyrrolothiazole Derivatives as Potential Antitubercular Agents. Bioorg. Med. Chem. Lett. 2015, 25, 4308-4313. [CrossRef] [PubMed]

57. Toumi, A.; Boudriga, S.; Hamden, K.; Daoud, I.; Askri, M.; Soldera, A.; Lohier, J.-F.; Strohmann, C.; Brieger, L.; Knorr, M. DiversityOriented Synthesis of Spiropyrrolo[1,2-a]isoquinolineDerivatives via Diastereoselective and Regiodivergent Three-Component 1,3-Dipolar Cycloaddition Reactions: In Vitro and in Vivo Evaluation of the Antidiabetic Activity of Rhodanine Analogues. Org. Chem. 2021, 86, 13420-13445. [CrossRef]

58. Chai, J.D.; Head-Gordon, M. Long-Range Corrected Hybrid Density Functionals with Damped Atom-Atom Dispersion Corrections. Phys. Chem. Chem. Phys. 2008, 10, 6615-6620. [CrossRef]

59. Barone, V.; Cossi, M. Quantum calculation of molecular energies and energy gradients in solution by a conductor solvent model. J. Phys. Chem. A 1998, 102, 1995-2001. [CrossRef]

60. Cossi, M.; Scalmani, G.; Rega, N.; Barone, V. New developments in the polarizable continuum model for quantum mechanical and classical calculations on molecules in solution. J. Chem. Phys. 2002, 117, 43-54. [CrossRef]

61. Rattan, A. Antimicrobials in Laboratory Medicine; B.I. Churchill Livingstone: New Delhi, India, 2000; Volume 85, p. 108. 
62. Asad, M.; Arshad, M.N.; Asiri, A.M.; Khan, S.A.; Rehan, M.; Oves, M. Synthesis, Characterization, Molecular Docking and Antimicrobial Activity of Novel Spiropyrrolidine Derivatives. Polycycl. Aromat. Compd. 2021. [CrossRef]

63. Hassaneen, H.M.E.; Eid, E.M.; Eid, H.A.; Farghaly, T.A.; Mabkhot, Y.N. Facial Regioselective Synthesis of Novel Bioactive Spiropyrrolidine/Pyrrolizine-Oxindole Derivatives via a Three Components Reaction as Potential Antimicrobial Agents. Molecules 2017, 22, 357. [CrossRef] [PubMed]

64. Frisch, M.J.; Trucks, G.W.; Schlegel, H.B.; Scuseria, G.E.; Robb, M.A.; Cheeseman, J.R.; Scalmani, G.; Barone, V.; Petersson, G.A.; Nakatsuji, H. Gaussian 16, Revision B.01; Gaussian, Inc.: Wallingford, CT, USA, 2016.

65. Miar, M.; Shiroudi, A.; Pourshamsian, K.; Oliaey, A.R.; Hatamjafari, F. Theoretical investigations on the HOMO-LUMO gap and global reactivity descriptor studies, natural bond orbital, and nucleus-independent chemical shifts analyses of 3-phenylbenzo[d] thiazole-2(3H)-imine and its para-substituted derivatives: Solvent and substituent effects. J. Chem. Res. 2020, 45, 147-158. [CrossRef]

66. Pearson, R.G. Hard and Soft Acids and Bases. J. Am. Chem. Soc. 1963, 85, 3533-3539. [CrossRef]

67. Erol, M.; Celika, I.; Kuyucuklu, G. Synthesis, Molecular Docking, Molecular Dynamics, DFT and Antimicrobial Activity Studies of 5-substituted-2-(p-methylphenyl)benzoxazole Derivtives. J. Mol. Struct. 2021, 1234, 130151. [CrossRef]

68. Pearson, R.G. Chemical hardness and the electronic chemical potential. Inorg. Chim. Acta 1992, 198-200, 781-786. [CrossRef]

69. Pearson, R.G. Maximum Chemical and Physical Hardness. J. Chem. Ed. 1999, 76, 267-275. [CrossRef]

70. Islam, N.; Ghosh, D.C. On the Electrophilic Character of Molecules Through Its Relation with Electronegativity and Chemical Hardness. Int. J. Mol. Sci. 2012, 13, 2160. [CrossRef] [PubMed]

71. Bhat, A.R.; Dongre, R.S.; Almalki, F.A.; Berredjem, M.; Aissaoui, M.; Touzani, R.; Ben Hadda, T.; Akhter, M.S. Synthesis, biological activity and POM/DFT/docking analyses of annulated pyrano[2,3-d]pyrimidine derivatives: Identification of antibacterial and antitumor pharmacophore sites. Bioorg. Chem. 2021, 106, 104480. [CrossRef]

72. Ghareeb, E.A.; Mahmoud, N.F.H.; El-Bordany, E.A.; El-Helw, E.A.E. Synthesis, DFT, and eco-friendly insecticidal activity of some $\mathrm{N}$-heterocycles derived from 4-((2-oxo-1,2-dihydroquinolin-3-yl)methylene)-2-phenyloxazol-5(4H)-one. Bioorg. Chem. 2021, 112, 104945. [CrossRef]

73. Uzun, S.; Esen, Z.; Koç, E.; Usta, N.C.; Ceylan, M. Experimental and density functional theory (MEP, FMO, NLO, Fukui functions) and antibacterial activity studies on 2-amino-4-(4-nitrophenyl)-5,6-dihydrobenzo [h] quinoline-3-carbonitrile. J. Mol. Struct. 2019, 1178, 450-457. [CrossRef]

74. Lipinski, C.A. Lead- and drug-like compounds: The rule-of-five revolution. Drug Discov. Today Technol. 2004, 1, 337-341. [CrossRef] [PubMed]

75. Veber, D.F.; Johnson, S.R.; Cheng, H.Y.; Smith, B.R.; Ward, K.W.; Kopple, K.D. Molecular properties that influence the oral bioavailability of drug candidates. J. Med. Chem. 2002, 45, 2615-2623. [CrossRef] [PubMed]

76. Dolomanov, O.V.; Bourhis, L.J.; Gildea, R.J.; Howard, J.A.K.; Puschmann, H. OLEX2: A complete structure solution, refinement and analysis program. J. Appl. Crystallogr. 2009, 42, 339-341. [CrossRef]

77. Sheldrick, G.M. SHELXT-Integrated space-group and crystal-structure determination. Acta Crystallogr. A 2015, 71, 3-8. [CrossRef] [PubMed]

78. Sheldrick, G.M. Crystal structure refinement with SHELXL. Acta Cryst. C71 2015, C71, 3-8. [CrossRef]

79. Dennington, R.; Keith, T.A.; Millam, J.M. GaussView, Version 6.0.16; Semichem Inc.: Shawnee Mission, KS, USA, 2016.

80. Pérez, P.; Domingo, L.R.; Aurell, M.J.; Contreras, R. Quantitative characterization of the global electrophilicity pattern of some reagents involved in 1,3-dipolar cycloaddition reactions. Tetrahedron 2003, 59, 3117-3125. [CrossRef]

81. Parr, R.G.; Szentpaly, L.; Liu, S. Electrophilicity Index. J. Am. Chem. Soc. 1999, 121, 1922-1924. [CrossRef]

82. Fukui, K. Role of frontier orbitals in chemical reactions. Science 1982, 21, 747-754. [CrossRef] 